COMPLETE

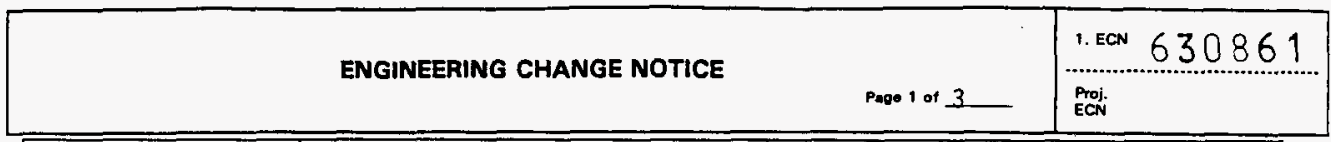

\begin{tabular}{|c|c|c|c|c|c|c|}
\hline \multirow{3}{*}{$\begin{array}{l}\text { 2. ECN Category } \\
\text { (mark one) } \\
\\
\text { Supplemental } \\
\text { Direct Revision } \\
\text { Change ECN } \\
\text { Temporary } \\
\text { Standby } \\
\text { Supersedure } \\
\text { Cancel/Void }\end{array}$} & \multirow{3}{*}{$\begin{array}{r}{[]} \\
{[X]} \\
{[]} \\
{[]} \\
{[]} \\
{[]} \\
{[]}\end{array}$} & \multicolumn{2}{|c|}{$\begin{array}{l}\text { 3. Originator's Name, Organization, MSIN, } \\
\text { and Telephone No. } \\
\text { EP Clements } / 84300 / G 1-13 / \\
376-4446\end{array}$} & \multicolumn{2}{|c|}{$\begin{array}{l}\text { 3a. USQ Required? } \\
{[] \text { Yes }[X] \text { No }}\end{array}$} & $\begin{array}{l}\text { 4. Date } \\
07 / 15 / 96\end{array}$ \\
\hline & & \multicolumn{2}{|c|}{$\begin{array}{l}\text { 5. Project Title/No./Work Order No. } \\
\text { GNS-12 PDC }\end{array}$} & \multicolumn{2}{|c|}{$\begin{array}{c}\text { 6. Bldg./Sys. /Fac. No. } \\
\text { NA }\end{array}$} & $\begin{array}{l}\text { 7. Approval Designator } \\
\text { SQD }\end{array}$ \\
\hline & & \multicolumn{2}{|c|}{$\begin{array}{l}\text { 8. Document Numbers Changed by this ECN } \\
\text { (includes sheet no. and rev.) } \\
\text { WHC-SD-TP-PDC-033, Rev. } 0\end{array}$} & \multicolumn{2}{|c|}{$\begin{array}{l}\text { 9. Related } \mathrm{ECN} \mathrm{No}(s) \text {. } \\
\text { NA }\end{array}$} & $\begin{array}{l}\text { 10. Related PO No. } \\
\text { NA }\end{array}$ \\
\hline \multirow{2}{*}{\multicolumn{2}{|c|}{$\begin{array}{l}\text { 11a. Modification Work } \\
\text { [] Yes (fill out Blk. } \\
111 \mathrm{~b} \text { ) } \\
{[X] \text { No (NA Blks. 11b, }} \\
11 c, 11 d \text { ) }\end{array}$}} & \multirow[t]{2}{*}{$\begin{array}{l}\text { 11b. Work Package } \\
\text { No. } \\
\text { NA }\end{array}$} & \multicolumn{2}{|c|}{$\begin{array}{l}\text { 11c. Modification Work Complete } \\
\text { NA }\end{array}$} & \multicolumn{2}{|c|}{$\begin{array}{l}\text { 11d. Restored to Original Condi- } \\
\text { tion (Temp. or Standby ECM only) } \\
\text { NA }\end{array}$} \\
\hline & & & \multicolumn{2}{|c|}{ Cog. Engineer signature \& Date } & \multicolumn{2}{|c|}{ Cog. Engineer signature \& Date } \\
\hline
\end{tabular}

12. Description of Change

The following changes are made to the GNS-12 PDC:

1. Inadvertently Teft U.S. Department of Energy (DOE), and Safety and Environmental

Advisory Council (SEAC) approvers off of original EDT 613314 which released the PDC for the GNS-12 Cask.

2. Change the GNS-12 from a Safety Evaluation for Packaging (SEP) to a Safety Analysis

Report for Packaging (SARP).

13a. Justification (mark one)

\begin{tabular}{llllllll}
$\begin{array}{lll}\text { Criteria Change } \\
\text { As-Found }\end{array}$ & {$[X]$} & Design Improvement & {[]} & Environmental & [] & Facility Deactivation \\
\hline
\end{tabular}

13b. Justification Details

1. Due to Highway Route Controlled Quantities (HRCQ) being transported in the GNS-12 Cask, DOE and SEAC approvals are required.

2. Based on the original GNS-12 PDC, the U.S. Department of Energy, Richland Operations Office (RL) requested the SEP be changed to a SARP due to the lack of a defined storage location greater than five years. The SARP justification allows the cask and its contents the ability to be transported onsite if a suitable permanent storage location is identified.

14. Distribution (include name, MSIN, and no. of copies) See attached.

A-7900-013-2 (11/94) GEF095 


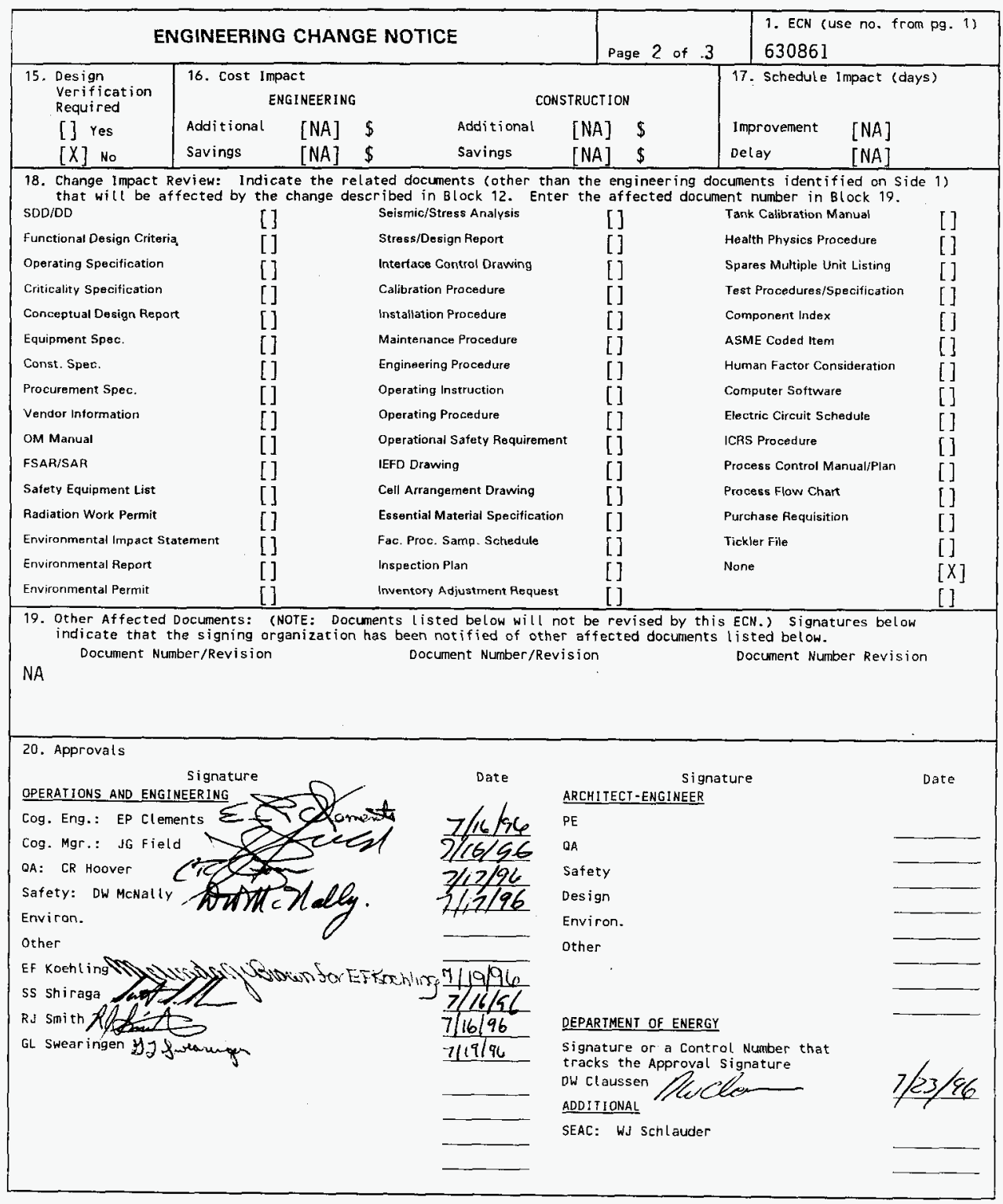




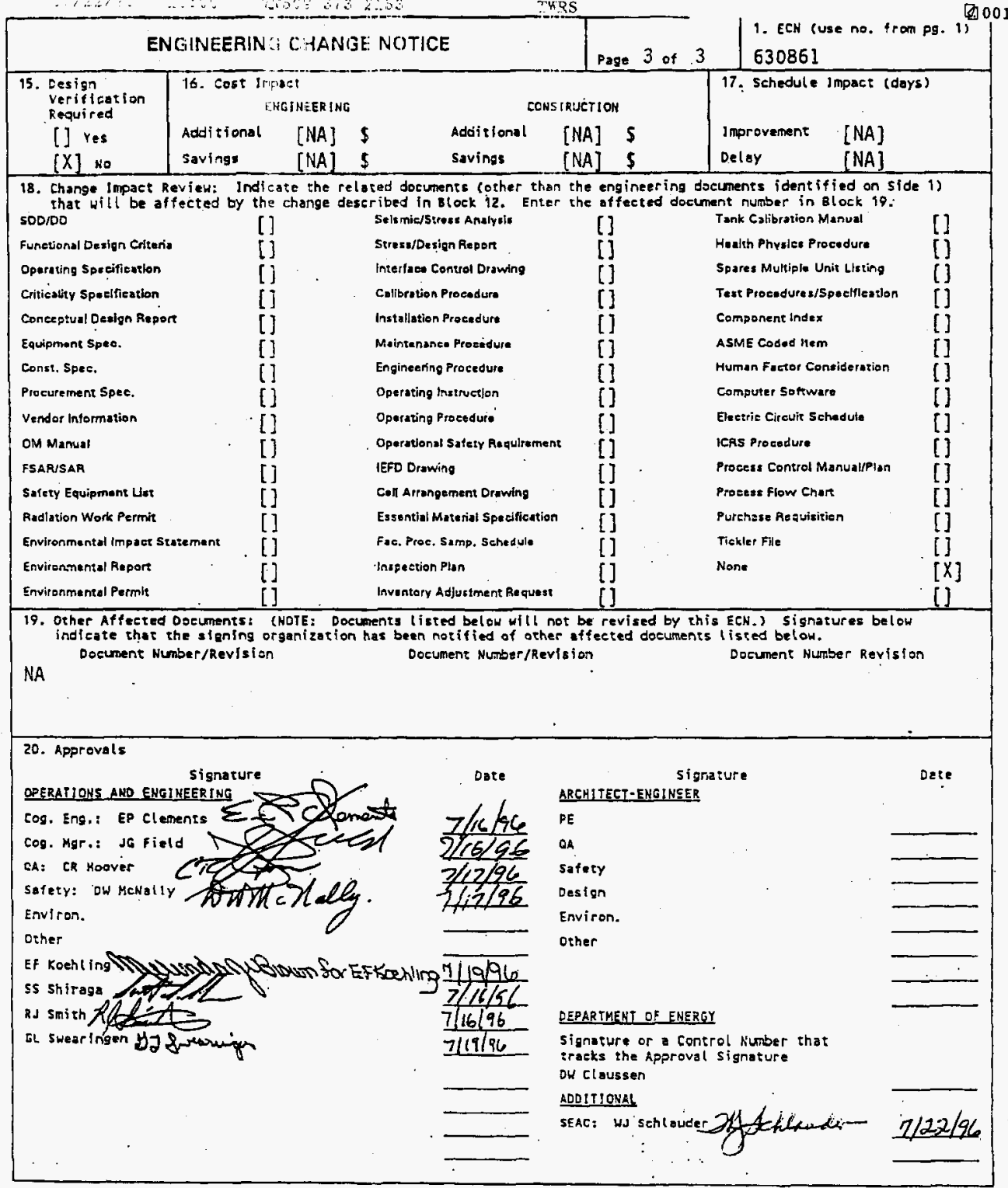




\title{
GNS-12 Packaging Design Criteria
}

\author{
E. P. Clements
}

Westinghouse Hanford Company, Richland, WA 99352

U.S. Department of Energy Contract DE-AC06-87RL10930

$\begin{array}{llll}\text { EDT/ECN: } & \text { ECN } 630861 & \text { UC: } 512 \\ \text { Org Code: } 84100 & \text { Charge Code: } & \\ \text { B\&R Code: } & \text { YN0100000 } & \text { Total Pages: } 50\end{array}$

Key Words: GNS-12, Packaging Design Criteria, PDC, Safety Analys is Report for Packaging, SARP

Abstract: The purpose of this Packaging Design Criteria (PDC) is to provide criteria for the Safety Analysis Report for Packaging (SARP) (Onsite). The SARP provides the evaluation to demonstrate that the onsite transportation safety criteria are met for the transport and storage of the 324 Building vitrified encapsulated material in the GNS-12 cask. In this application, the approved PDC provides a formal set of standards for the payload requirements, and guidance for the current cask transport configuration and a revised storage seal and primary lid modification design.

TRADEMARK DISCLAIMER. Reference herein to any specific commercial product, process, or service by trade name, trademark, manufacturer, or otherwise, does not necessarily constitute or imply its endorsement, recommendation, or favoring by the United States Government or any agency thereof or its contractors or subcontractors.

Printed in the United States of America. To obtain copies of this document, contact: WHC/BCS Document Contral Services, P.O. Box 1970, Mailstop H6-08, Richland WA 99352, Phone (509) 372-2420; Fax (509) 376-4989.
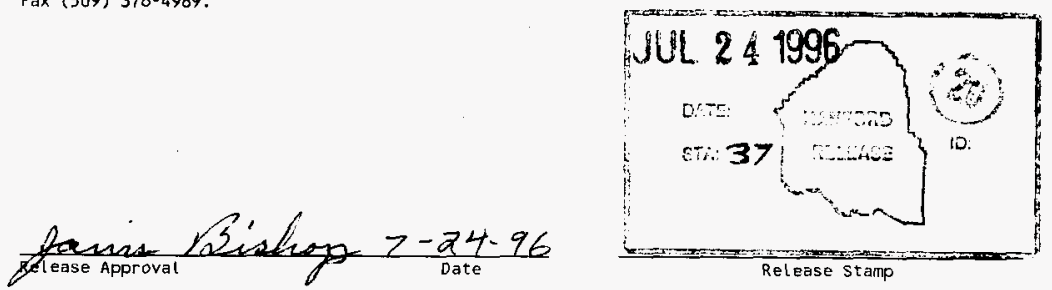

\section{Approved for Public Release}




\section{RECORD OF REVISION}

(1) Document Number

WHC-SD-TP-PDC-033

Page 1

(2) Title

GNS-12 Packaging Design Criteria

CHANGE CONTROL RECORD

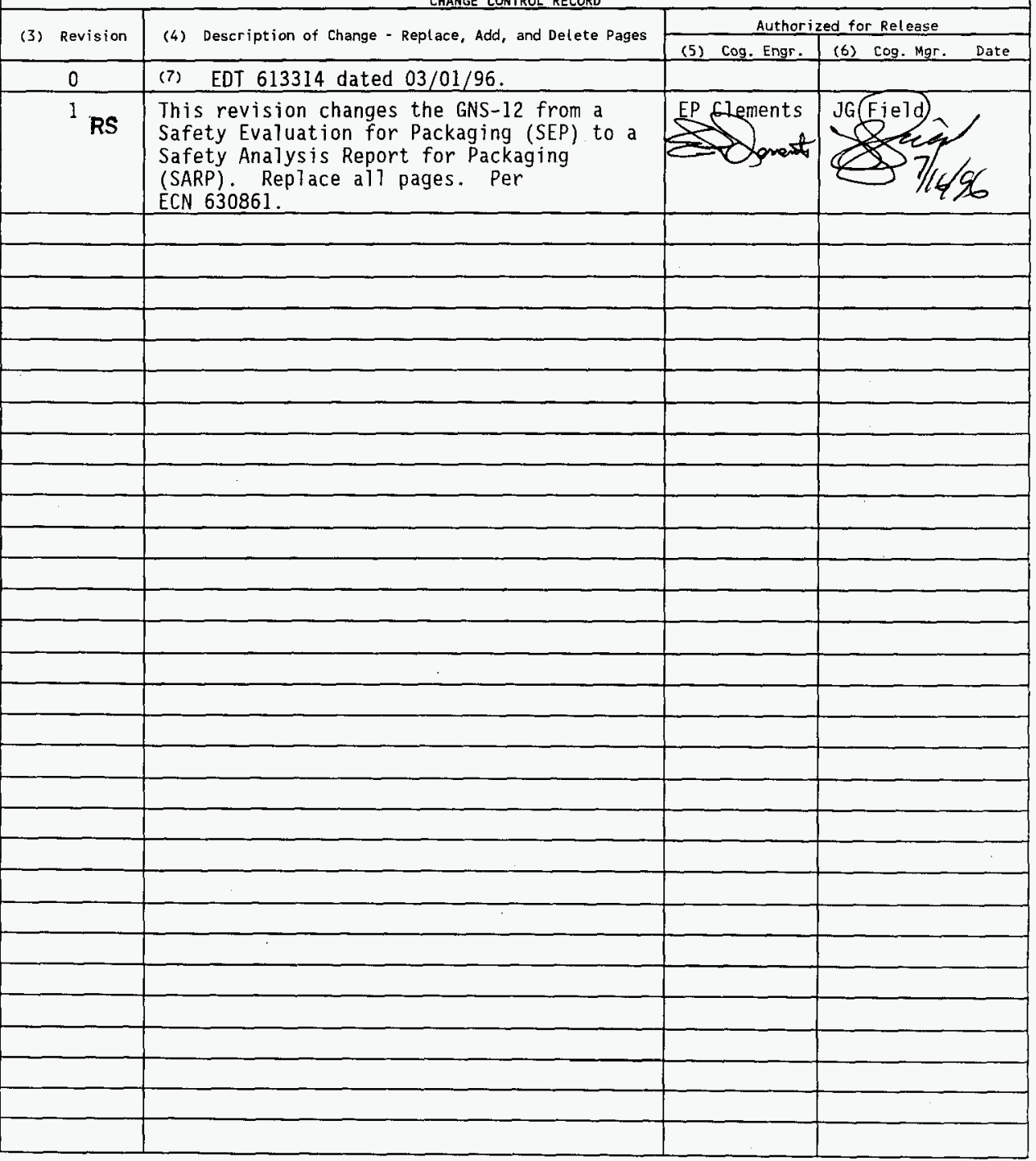


WHC-SD-TP-PDC-033 Rev. 1

\section{CONTENTS}

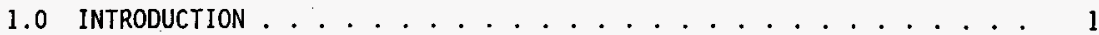

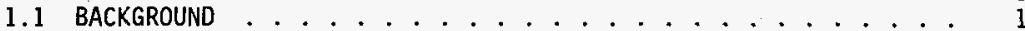

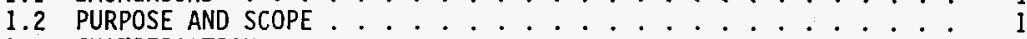

1.3. JUSTIFICATION . . . . . . . . . . . . . . . 1

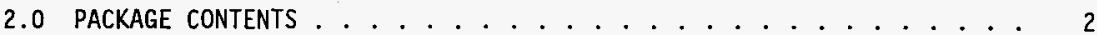

2.1 PAYLOAD DESCRIPTION . . . . . . . . . . . . . . . . 2

2.2 RADIOACTIVE MATERIALS .................. . . . . 3

2.2.1 Source Term . . . . . . . . . . . . . . . . . 3

2.3 CHEMICAL CONSTITUENT SOURCE TERM .............. 5

2.4 GAS GENERATION .................... 6

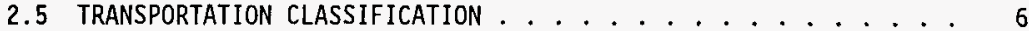

2.6 FISSILE CLASSIFICATION ................... . . . . 7

2.7 CONTENT RESTRICTIONS .................... . . . 7

3.0 FACILITY OPERATIONS ${ }^{\circ}$.

3.1 ORIGINATING SITE - 324 BUILDING . . . . . . . . . . . . . . . 7

3.2 DESTINATION SITE - 200 WEST .................. 7

4.0 PACKAGING/TRANSPORT SYSTEM DESIGN . . . . . . . . . . . . . . . 7

4.1 GENERAL . . . . . . . . . . . . . . . . . . . . . . . 7

4.2 PACKAGING DESIGN CRITERIA . . . . . . . . . . . . . . . . . . . . 8

4.2.1 Packaging Specification and Materiais . . . . . . . . . 8

4.2.2 Packaging Dimensions . . . . . . . . . . . . . . 8

4.2.3 Maximum Gross Weight . . . . . . . . . . . . . . . 10

4.2.4 Tiedown Attachments . . . . . . . . . . . . . . 10

4.2.5 Lifting Attachments . . . . . . . . . . . . . . 10

4.2.6 Venting .................... . . . 10

4.2.7 Closure Design and Containment . . . . . . . . . . . 12

4.2.8 Shielding ................... . . . 13

4.2.9 Service Life . . . . . . . . . . . . . . . . . . . . . . . . . . . . 13

4.2.10 Chemical and Gajvanic Reactions . . . . . . . . . . . . . . 13

4.2.11 Surface Contamination ................ . . . 13

4.3 TRANSPORT SYSTEM . . . . . . . . . . . . . . . . . . 13

4.3.1 Transport Vehicie . . . . . . . . . . . . . . . 13

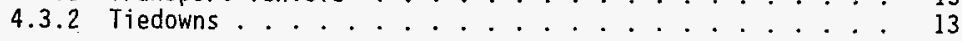

5.0 GENERAL REQUIREMENTS . . . . . . . . . . . . . . . . . . . . . . 14

5.1 TRANSPORTATION EVALUATION REQUIREMENTS . . . . . . . . . . . . . 14

5.1.1 Normal Transfer Conditions................ . . . 14

5.1 .2 Accident Events . . . . . . . . . . . . . . . . . . . 14

5.1 .3 Thermal . . . . . . . . . . . . . . . . . 15

5.2 AS LOW AS REASONABLY ACHIEVABLE . . . . . . . . . . . . . . . . . 15

5.3 QUALITY ASSURANCE . . . . . . . . . . . . . . . . . . . . . . . . . . . 15

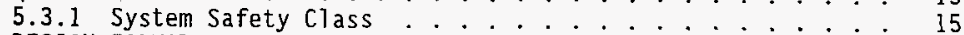

5.4 DESIGN FORMAT

5.5 ENVIRONMENTAL COMPLIANCE

5.6 MAINTENANCE . . . . . . . . . . . . . . . . . . . . . . . . . . 16

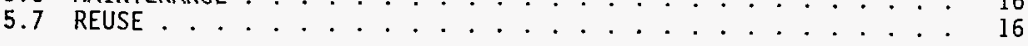


WHC-SD-TP-PDC-033 Rev. 1

CONTENTS (cont)

6.0 APPENDICES ........................ 16

6.1 REFERENCES ............................ 16

6.2 SAFETY CLASS EVALUATION . . . . . . . . . . . . 18

6.3 COMPETENT AUTHORITY . . . . . . . . . . . . 31

\section{LIST OF FIGURES}

1. Heat Source (Canister) Payload Configuration ........... 2

2 Canister Fitling Process . . . . . . . . . . . . . . . 3

3 Canister Campaign Graphs ................. 4

4 Assembled Cask(s) and Primary Lid Configuration ......... 9

5 Twenty Foot Open All Closed Transport Container . . . . . . . . . . 11

6 Primary Lid Sealing System ................ 12

\section{LIST OF TABLES}

1 GNS-12 Source Term ... . . . . . . . . . . . . . . . . . . 5

2 Nominal Glass Chemical Composition . . . . . . . . . . . . . 6

3 GNS-12 Cask Dimensions ................... . . . . 8

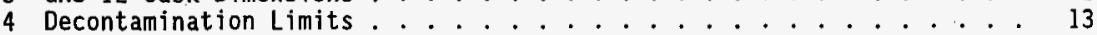




\section{LIST OF TERMS}

$\begin{array}{ll}\text { ALARA } & \text { As Low As Reasonably Achievable } \\ \text { Bq } & \text { Bequerels } \\ \text { CFR } & \text { Code of Federal Regulations } \\ \text { Ci } & \text { Curie } \\ \text { CWC } & \text { Central Waste Complex } \\ \text { DOE } & \text { U.S. Department of Energy } \\ \text { DOT } & \text { U.S. Department of Transportation } \\ \text { EDE } & \text { effective dose equivalent } \\ \text { FRG } & \text { Federal Republic of Germany } \\ \text { HRCQ } & \text { Highway Route Controlled Quantity } \\ \text { IAEA } & \text { International Atomic Energy Agency } \\ \text { mm } & \text { millimeters } \\ \text { mrem/h } & \text { millirem per hour } \\ \text { PDC } & \text { Packaging Design Criteria } \\ \text { Pacific } & \\ \quad \text { Northwest } & \text { Pacific Northwest National Laboratory } \\ \text { PTB } & \text { German Federal Physical-Technical Institution, Braunschweig } \\ \text { QA } & \text { Quality Assurance } \\ \text { R/h } & \text { Roentgen per hour } \\ \text { RL } & \text { U.S. Department of Energy, Richland Operations Office } \\ \text { RQ } & \text { Reportable Quantity } \\ \text { SAR } & \text { Safety Analysis Report } \\ \text { SARP } & \text { Safety Analysis Report for Packaging } \\ \text { SV/h } & \text { Sieverts per hour } \\ \text { WHC } & \text { Westinghouse Hanford Company } \\ & \end{array}$


WHC-SD-TP-PDC-033 Rev, 1

\section{GNS-12 PACKAGING DESIGN CRITERIA}

\subsection{INTRODUCTION}

\subsection{BACKGROUND}

Encapsulated vitrified materials (Isotopic Heat Sources) are currently stored in the Pacific Northwest National Laboratory (Pacific Northwest) 324 Building located in the 300 Area. As part of the 324 Building transition program, the vitrified material, encapsulated in (steel canisters); must be removed. The canisters will be transported onsite in the GNS-12 cask for interim storage until final disposition of the material is determined. The GNS-12 cask, designed and fabricated by GNS Gesellschaft für Nuklear-Service $\mathrm{mbH}$, Essen, was a certified Type B(U) Packaging, which complies with the 1985 Safety Series No. 6 (IAEA 1990) requirements of the International Atomic Energy Agency (IAEA) for transport of sealed canisters of vitrified radioactive materials. The cask held a Competent Authority Certification [USA/0441/B(U), Rev. O $(1991-1993)$, see Section 6.3] by the U.S. Department of Transportation (DOT) for the same material. The GNS-12 cask was originally designed to transport isotopic heat sources $\left({ }^{137} \mathrm{Cs} /{ }^{90} \mathrm{Sr}\right.$ borosilicate glass) encapsulated in steel canisters from the USA to the Federal Republic of Germany (FRG). The cask, which can accommodate up to three such canisters, is designed and fabricated as a composite type container with lead shielding in between outer and inner steel liners.

\subsection{PURPOSE AND SCOPE}

The purpose of this Packaging Design Criteria (PDC) is to provide criteria for the Safety Analysis Report for Packaging (SARP) (Onsite). The SARP provides the evaluation to demonstrate that the onsite transportation safety criteria are met for the transport and storage of the 324 Building vitrified encapsulated material in the GNS-12 cask. In this application, the approved PDC provides a formal set of standards for the payload requirements, and guidance for the current cask transport configuration and a revised storage seal and primary lid modification design.

The SARP will be approved by Pacific Northwest and the Westinghouse Hanford Company (WHC), including Quality Assurance (QA) and Safety, to authorize onsite interarea transfer. Due to the large quantities of radioactive materials being classified as Highway Route Controlled Quantity (HRCQ), the SARP will also require the approval of the U.S. Department of Energy (DOE), Richland Operations office (RL).

\subsection{JUSTIFICATION}

Presently, there are 32 steel canisters being stored in the 324 Building. This material must be removed to allow for the 324 Building to be decommissioned. The cask that will be used for the campaign must:

1. Provide adequate shielding for operational personnel. 
2. Maintain the encapsulated vitrified material in its original configuration during normal and accident transport conditions.

3. Effectively dissipate payload thermal heat loads.

4. Maintain the material in a nonreactive environment during storage.

5. Be compatible with the 324 Building facility and operation requirements.

6. Provide ease of operation for loading, unloading, transporting, maintaining, and storing.

The packaging that best meets these requirements is the GNS-12 cask.

\subsection{PACKAGE CONTENTS}

\subsection{PAYLOAD DESCRIPTION}

The payload (Figure 1) for the GNS-12 packaging system will consist of borosilicate glass encapsulated in steel canisters (PNL-6790/UC-510). The borosilicate glass matrix constituents were immobilized to yield a product with a predetermined thermal decay heat and surface radiological dose rate. The canisters' radiochemical characteristics for thermal heat load range between 1330 and $2285 \mathrm{~W}$ each. Radiological gamma exposure rates on contact are between $112,000 \mathrm{R} / \mathrm{h}(1,120 \mathrm{~Sv} / \mathrm{h})$ to $310,000 \mathrm{R} / \mathrm{h}(3,100 \mathrm{~Sv} / \mathrm{h})$. For purposes of this PDC, $100 \mathrm{R} / \mathrm{h}$ is conservatively assumed to equal I $\mathrm{Sv} / \mathrm{h}$.

Figure 1. Heat Source (Canister) Payload Configuration.

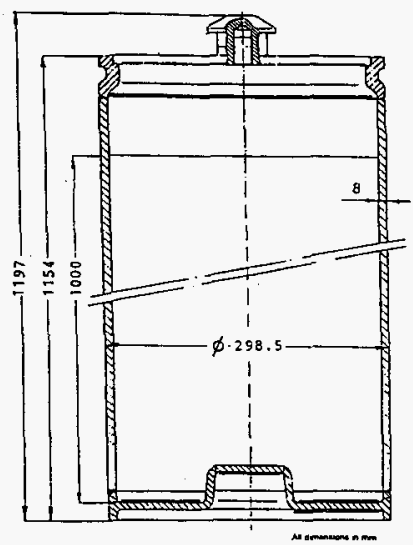




\subsection{RADIOACTIVE MATERIALS}

The vitrified encapsulated material to be transported contains significant amounts of ${ }^{137} \mathrm{Cs}$ and ${ }^{90} \mathrm{Sr}$. Three specific campaigns (RLFCM-7, RLFCM-8, and RLFCM-9) were performed by Pacific Northwest during heat source (canister) development. Figure 2 shows the canister filling process. Figure 3 provides graphs depicting the specific oxide in glass weight percent of all three canister campaigns.

Figure 2. Canister Filling Process.

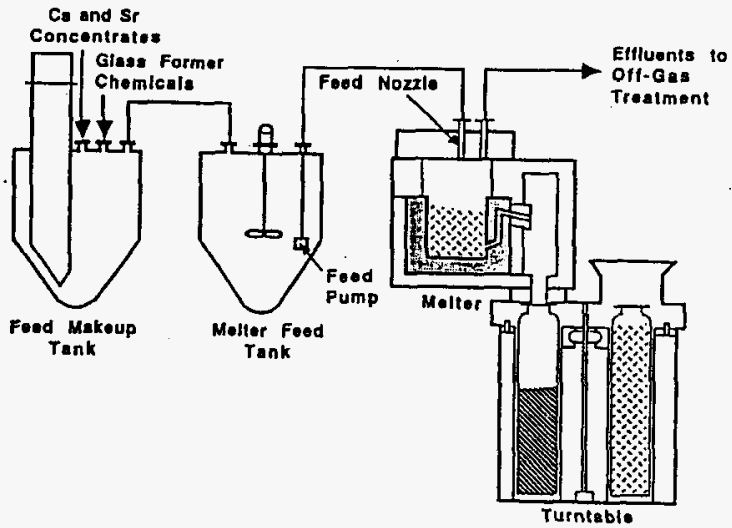

\subsubsection{Source Term}

The worst case canister inventory was taken from the Safety Analysis Report (SAR) for the CASTOR GSF cask (GNS 1990). The GNS-12 cask will contain the same type of material that the CASTOR GSF cask will contain; therefore, the source term information from the CASTOR GSF cask (GNS 1990) also applies to the GNS-12 cask. Table 1 lists the worst case canister activities from the CASTOR GSF SAR and the activities of their equilibrium daughter as calculated by ORIGEN. It also lists the maximum cask activities assuming a loading of three canisters per cask. Note also that the daughter products included in Table 1 contribute 7 ess than $1 \%$ to the total radiological dose. 
Figure 3. Canister Campaign Graphs.

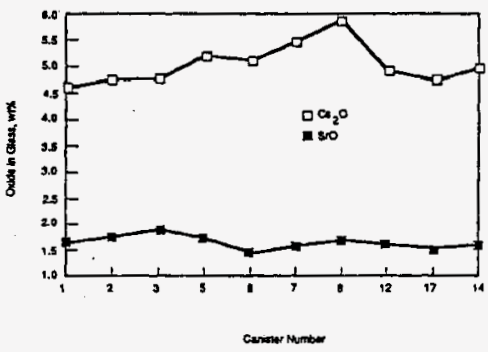

MLFa47 Cesium and strontiun comentrations

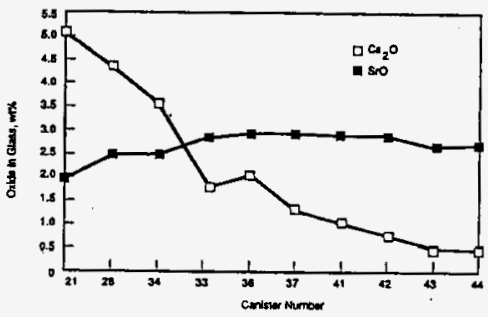

RIFCM-8 Cesiua and Strontion Concentrations

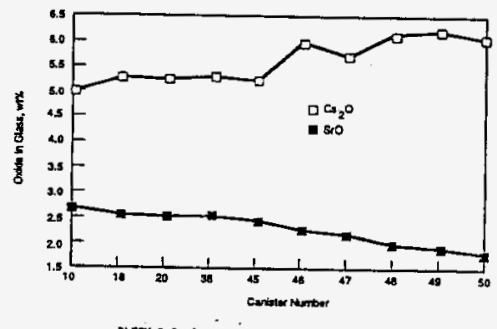

RLFan-9 Cestum and strontiva conentriations 
WHC-SD-TP-PDC-033 Rev. 1

Table 1. GNS-12 Source Term.

\begin{tabular}{|c|c|c|c|c|c|}
\hline Nuclide & $\begin{array}{l}\text { Single Canister } \\
\text { Activity, } \mathrm{Ci}\end{array}$ & $\begin{array}{c}\text { Maximum Cask } \\
\text { Activity, Cr }\end{array}$ & Nuclide & $\begin{array}{l}\text { Single Canister } \\
\text { Activity. Ci }\end{array}$ & $\begin{array}{l}\text { Maximum Cask } \\
\text { Activity, CF }\end{array}$ \\
\hline${ }^{\infty} \mathrm{Sr}$ & $2.1 E+05$ & $6.3 E+05$ & ${ }^{203} \mathrm{Th}$ & $3,4 \mathrm{E}-06$ & $1.0 \mathrm{E}-05$ \\
\hline or & $2.1 E+05$ & $6.3 E+05$ & ${ }^{204 \mathrm{mPa}}$ & $3.4 \mathrm{E}-06$ & $1.0 \mathrm{E}-05$ \\
\hline${ }^{197} \mathrm{Cs}$ & $3.0 E+05$ & $9.0 \mathrm{E}+05$ & ${ }^{234} \mathrm{U}$ & $5.3 \mathrm{E} \cdot 06$ & $1.6 \mathrm{E}-05$ \\
\hline${ }^{197 m \mathrm{Ba}}$ & $2.8 \mathrm{E}+05$ & $8.4 E+05$ & ${ }^{236} \mathrm{U}$ & $1.9 \mathrm{E}-07$ & $5.7 \mathrm{E}-07$ \\
\hline${ }^{200} \mathrm{~T}$ & 1.2 E.04 & $3.6 \mathrm{E}-04$ & ${ }^{250} \mathrm{U}$ & $4.4 \mathrm{E}-07$ & $1.3 \mathrm{E}-06$ \\
\hline${ }^{12} \mathrm{~Pb}$ & $3.3 \mathrm{E}-04$ & 9.9 E-04 & ${ }^{23} \mathrm{U}$ & 5.5 E.05 & $1,7 \mathrm{E}-\mathrm{O} 4$ \\
\hline${ }^{312} \mathrm{Bi}$ & $3.3 \mathrm{E}-04$ & 9.9 E- 04 & ${ }^{2340} \mathrm{U}$ & $3.4 \mathrm{E}-06$ & $1.0 \mathrm{E}-05$ \\
\hline${ }^{212} \mathrm{Po}$ & $2.1 \mathrm{E}-04$ & $6.3 \mathrm{E}-04$ & ${ }^{230} \mathrm{~Np}$ & $2.0 \mathrm{E}-01$ & $6.0 \mathrm{E}-01$ \\
\hline${ }^{210} \mathrm{Po}$ & $3.3 \mathrm{E}-04$ & $9.9 \mathrm{E}-04$ & ${ }^{238} \mathrm{Pu}$ & $1.7 \mathrm{E}-01$ & 5.1 E-01 \\
\hline${ }^{200} \mathrm{Rn}$ & $3.3 \mathrm{E}-0.4$ & $9.9 \mathrm{E}-04$ & ${ }^{230} \mathrm{Pu}$ & $1.7 \mathrm{E}-01$ & 5.1 E-01 \\
\hline${ }^{224} \mathrm{RA}$ & $3,3 \mathrm{E}-04$ & $9.9 \mathrm{E}-04$ & 200Pu & $5.6 \mathrm{E}-02$ & $1.7 \mathrm{E} \cdot 01$ \\
\hline${ }^{22:} \mathrm{Ra}$ & $3.3 \mathrm{E}-04$ & $9.9 \mathrm{E}-04$ & ${ }^{241} \mathrm{Pu}$ & $2.3 E+\infty 0$ & $6.9 \mathrm{E}+00$ \\
\hline${ }^{278} \mathrm{Ac}$ & 3.3 E.04 & $9.9 \mathrm{E}-04$ & ${ }^{242} \mathrm{Pu}$ & $4.6 \mathrm{E}-05$ & $1.4 \mathrm{E}-04$ \\
\hline${ }^{278} \mathrm{Th}$ & $3.3 \mathrm{E}-04$ & $9.9 \mathrm{E}-04$ & ${ }^{241} \mathrm{Am}$ & $3.4 \mathrm{E}-01$ & $1.0 E+00$ \\
\hline${ }^{2 \pi} T h$ & $1.9 \mathrm{E}-07$ & $5.7 \mathrm{E}-07$ & ${ }^{243} \mathrm{Am}$ & $2.0 \mathrm{E}-01$ & $6.0 \mathrm{E}-01$ \\
\hline sth & $3.3 \mathrm{E}-04$ & 9.9 E-04 & TOTALS & $1.0 E+06$ & $3.0 \mathrm{E}+06$ \\
\hline
\end{tabular}

- Assumes a maximum of three canisters will be loaded in the GNS-12 cask.

\subsection{CHEMICAL CONSTITUENT SOURCE TERM}

The SARP will evaluate how the vitrified encapsulated material will perform during and after accident events. The packaging system and administrative controls set forth in the SARP ensure the vitrified material configuration matrix is maintained. Table 2 gives the nominal glass compositions for all three canister productions. 
WHC-SD-TP-PDC-033 Rev. 1

Table 2. Nominal Glass Chemical Composition.

\begin{tabular}{|c|c|c|c|}
\hline $\begin{array}{c}\text { Oxide } \\
\text { Compound }\end{array}$ & $\begin{array}{l}\text { Average Glass Compasition } \\
\text { RLFCM-7, wt \% } \\
\end{array}$ & $\begin{array}{c}\text { Averago Glass Composition } \\
\text { RLFCM-8, wt\% }\end{array}$ & $\begin{array}{l}\text { Average Glass Composition } \\
\text { RLFCM-9, } w \%\end{array}$ \\
\hline $\mathrm{Al}_{2} \mathrm{O}_{3}$ & 2.88 & 2.58 & 2.17 \\
\hline $\mathrm{B}_{2} \mathrm{O}_{3}$ & 13.68 & 14.65 & 14.84 \\
\hline $\mathrm{BaO}$ & 1.05 & 1.13 & 1.02 \\
\hline $\mathrm{CaO}$ & 1.52 & 1.25 & 0.79 \\
\hline $\mathrm{CoO}_{2}$ & 0.06 & 0.05 & 0.07 \\
\hline $\mathrm{Cr}_{2} \mathrm{O}_{7}$ & 0.58 & 0.38 & 0.45 \\
\hline $\mathrm{Cs}_{2} \mathrm{O}$ & 5.02 & 2.08 & 5.74 \\
\hline $\mathrm{Fe}_{2} \mathrm{O}_{3}$ & 11.18 & 10.10 & 9.93 \\
\hline $\mathrm{La}_{2} \mathrm{O}_{3}$ & 1.04 & 1.07 & 1.53 \\
\hline $\mathrm{H}_{2} \mathrm{O}$ & 0.31 & 0.00 & 0.00 \\
\hline Mgo & 0.78 & 0.54 & 0.44 \\
\hline $\mathrm{MnO}_{2}$ & 0.80 & 1.20 & 1.11 \\
\hline $\mathrm{MoO}_{\mathrm{a}}$ & 0.05 & 0.00 & 0.00 \\
\hline $\mathrm{Na}_{2} \mathrm{O}$ & 16.50 & 13.22 & 11.58 \\
\hline $\mathrm{Nd}_{2} \mathrm{O}_{3}$ & 0.65 & 0.71 & 0.89 \\
\hline Nio & 0.39 & 0.25 & 0.44 \\
\hline Pbo & 0.16 & 0.00 & 0.00 \\
\hline $\mathrm{RuO}_{2}$ & 0.02 & 0.00 & 0.00 \\
\hline $\mathrm{SiO}_{2}$ & 41.25 & 48.02 & 46.59 \\
\hline sto & 1.65 & 2.67 & 2.34 \\
\hline $\mathrm{TIO}_{2}$ & 0.19 & 0.07 & 0.03 \\
\hline Zno & 0.08 & 0.01 & 0.00 \\
\hline \multirow[t]{2}{*}{$\mathrm{ZrO}_{2}$} & 0.15 & 0.04 & 0.05 \\
\hline & 100.00 & 100.00 & 100.00 \\
\hline
\end{tabular}

\subsection{GAS GENERATION}

Based upon the glass form of the radioactive material and the containment provided by the canisters, there will be no gas generation.

\subsection{TRANSPORTATION CLASSIFICATION}

For transportation purposes, the vitrified encapsulated material of this packaging is considered Type B, Reportable Quantities (RQ), HRCQ, Yellow III, Radioactive Material in accordance with the Hazardous Material Packaging and Shipping, WHC-CM-2-14. 
WHC-SD-TP-PDC-033 Rev. 1

\subsection{FISSILE CLASSIFICATION}

There is less than $15 \mathrm{~g}$ of fissile material; therefore, the payload shall be classified as fissile excepted for transportation.

\subsection{CONTENT RESTRICTIONS}

A single GNS-12 cask may contain up to a maximum of three steel GNF/GSF canisters. Each canister can contain a maximum activity of $297.0 \mathrm{kCi}$ $\left(1.1 \times 10^{16} \mathrm{~Bq}\right){ }^{137} \mathrm{Cs}$ and $207.9 \mathrm{kCi}\left(7.7 \times 10^{15} \mathrm{~Bq}\right){ }^{90} \mathrm{Sr} /{ }^{90} \mathrm{Y}$, respectively. The maximum thermal wattage of each canister is $2285 \mathrm{~W}$. The maximum weight of the payload without the basket (three canisters loaded) is $1650 \mathrm{lb}(750 \mathrm{~kg}$ ).

\subsection{FACILITY OPERATIONS}

\subsection{ORIGINATING SITE - 324 BUILDING}

The vitrified material will be loaded in the GNS-12 cask. All cask loading shall take place in the 324 Hot Cells. The casks will be loaded onto the transport vehicle in the configuration of the open-all closed transport system.

\subsection{DESTINATION SITE - 200 WEST AREA}

The current storage site of the loaded GNS-12 cask has not been determined at this time. The SARP will identify this location and applicable requirements. The cask transport system can be unloaded from the transport vehicle if required and $p$ laced in the appropriate storage site.

\subsection{PACKAGING/TRANSPORT SYSTEM DESIGN}

\subsection{GENERAL}

The GNS-12 cask consists of a welded stainless steel and lead composite structure. The cask body and closure lid and seals form the containment system ensuring the integrity of the package. A basket is inserted in the cavity of the cask in order to secure the contents. The cask is handled with the aid of lifting trunnions. In order to reduce the load during transport accidents, impact limiters are mounted over the ends of the cask.

The GNS-12 cask will be modified for the onsite transport and storage of vitrified encapsulated material. The modification will consist of replacing one of the double elastomeric containment seals in the primary 1 id with a metallic seal. This SARP will evaluate and certify all three transport configurations (double elastomer, WHC design, and German lid modification). No other design changes are planned. 
WHC-SD-TP-PDC-033 Rev. 1

\subsection{PACKAGING DESIGN CRITERIA}

\subsubsection{Packaging Specification and Materials}

4.2.1.1 GNS-12 Cask. The GNS-12 cask (Figure 4) structural design covers all safety related parts of the packaging in compliance with the requirements for transport. This includes analys is of all considered loads, stresses, and safety factors which are essential to meet the transportation standards for a Type $B$ packaging under normal operations and hypothetical accident conditions. The GNS-12 cask structural design is based on a $30 \mathrm{ft}(9 \mathrm{~m})$ drop criteria.

The cask is designed for a $g$-loading of $220 \mathrm{~g}$ for an end drop. The GNS-12 cask incorporates five basic components which maintain the structural integrity and safe confinement of its payload.

The five basic components are:

1. Impact limiters, which protect the ends of the outer cask during transport.

2. Outer shell (secondary containment).

3. Inner liner (primary containment).

4. Lid and seal systems (primary lid, double seals).

5. Basket to keep the payload in position (canisters).

\subsubsection{Packaging Dimensions}

Table 3 provides the nominal dimensions of the GNS-12 cask.

Table 3. GNS-12 Cask Dimensions.

\begin{tabular}{|l|c|c|}
\hline \multirow{2}{*}{ Description } & \multicolumn{2}{c|}{ Dimensions } \\
\cline { 2 - 3 } & in. & $\mathrm{cm}$ \\
\hline \hline Overall height with 7id & 64.4 & 163.6 \\
\hline Outside width (with impact limiters) & 65.0 & 165.0 \\
\hline Outside length (with impact limiters) & 81.0 & 205.6 \\
\hline Container body height (with 7id) & 64.4 & 163.6 \\
\hline Inner cavity height (with 1id) & 48.0 & 122.0 \\
\hline Inner cavity diameter & 28.5 & 72.3 \\
\hline Inner cavity length (without lid) & 57.0 & 144.0 \\
\hline Lead shielding thickness (lid) & 3.0 & 8.0 \\
\hline Lead shielding thickness (body) & 4.0 & 10.0 \\
\hline
\end{tabular}


WHC-SD-TP-PDC-033 Rev. 1

Figure 4. Assembled Cask(s) and Primary Lid Configuration.
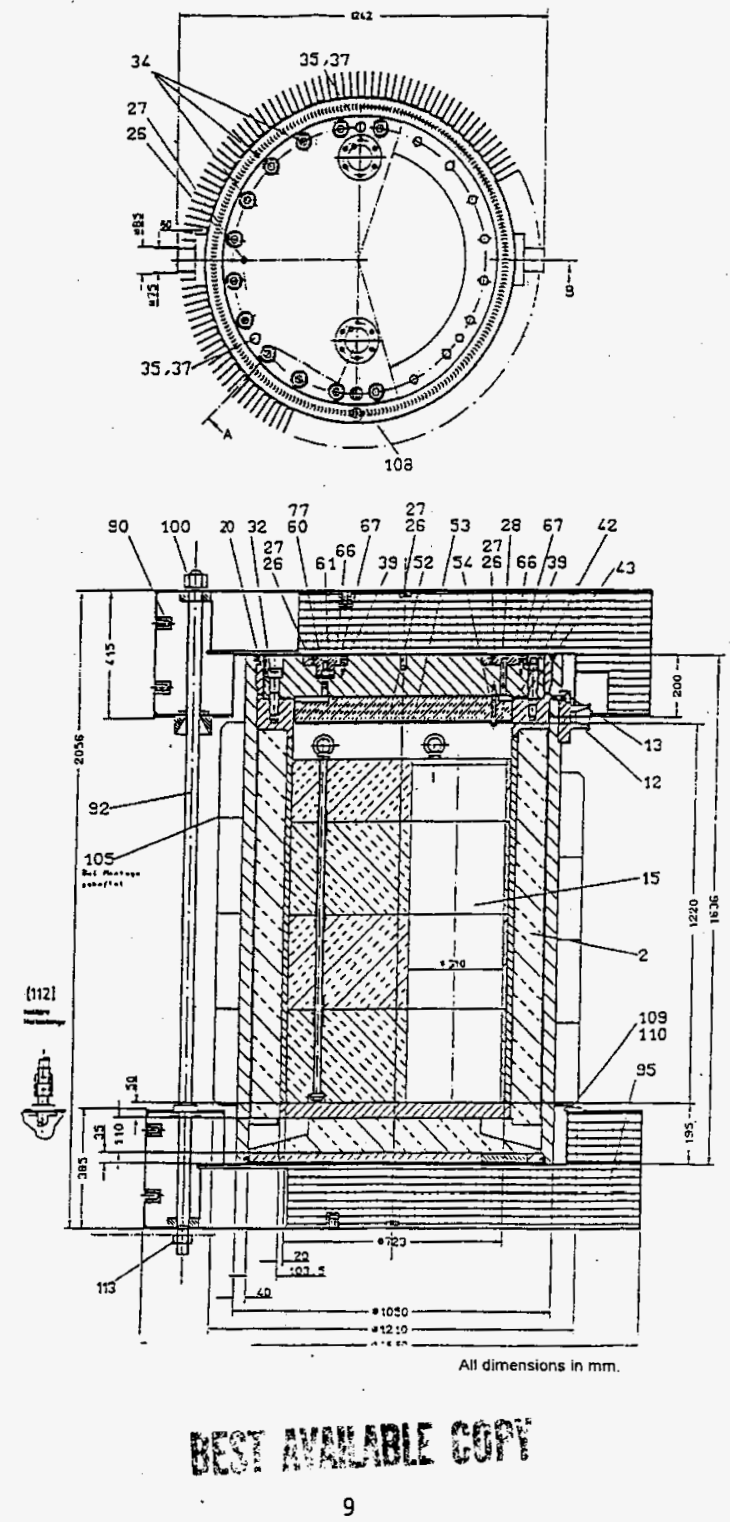


$$
\text { WHC-SD-TP-PDC-033 . Rev. I }
$$

\subsubsection{Maximum Gross Weight}

The empty weight of the GNS-12 cask with basket is $25,945 \mathrm{lb}$ $(11,766 \mathrm{~kg})$. The complete assembled cask (10aded) is $27,6001 \mathrm{~b}(12,500 \mathrm{~kg})$. The SARP shall confirm the maximum allowable payload weight.

\subsubsection{Tiedown Attachments}

Current]y, the cask has an engineered securement system for transport. This system incorporates the use of a closed transport container configuration (Figure 5). The SARP will evaluate the current engineered system as designed for meeting reasonable onsite transportation.

Tiedown or other attachments which are a structural part of the cask and used to secure the GNS-12 cask must have the capacity to withstand, without generating stress in any material of the GNS-12 cask in excess of yield strength, a static force applied to the center of gravity of the GNS-12 cask. The static force must have a vertical component of two times the gross weight of the fully laaded GNS-12 cask, a horizontal component along the direction in which the vehicle travels of ten times the weight of the fully loaded cask, and a horizontal component in the transverse direction of five times the weight of the fully loaded cask.

Any other structural part of the GNS-12 cask which could be used for securement must be capable of being rendered inoperable for securing the GNS-12 cask during transfer, or must have the strength equivalent required for the tiedown attachments to be used for such transfer applications.

Each tiedown attachment, which is a structural part of the GNS-12 cask, must be designed so that failure of the attachment under excessive load would not impair the ability of the GNS-12 cask to meet other requirements of this PDC.

\subsubsection{Lifting Attachments}

The lifting attachments for the packaging shall be capabie of lifting three times the total suspended weight without generating a combined stress or maximum tensile stress at any point in the load path in excess of the corresponding minimum yield strength of their materials of construction.

\subsubsection{Venting}

As presently designed, the cask does not vent to the surrounding atmosphere once the primary 1 id is installed and secured. The GNS-12 cask design incorporates a cavity drain, vacuum drying, and backfilling capability of the cask cavity with helium. This design eliminates the possibility of a hydrogen buildup in the cask cavity during transport and/or storage due to dry loading, and vacuum drying and testing. With respect to activity releases, the payload canister is considered part of the containment system. 
Figure 5. Twenty Foot Open A11 Closed Transport Container.
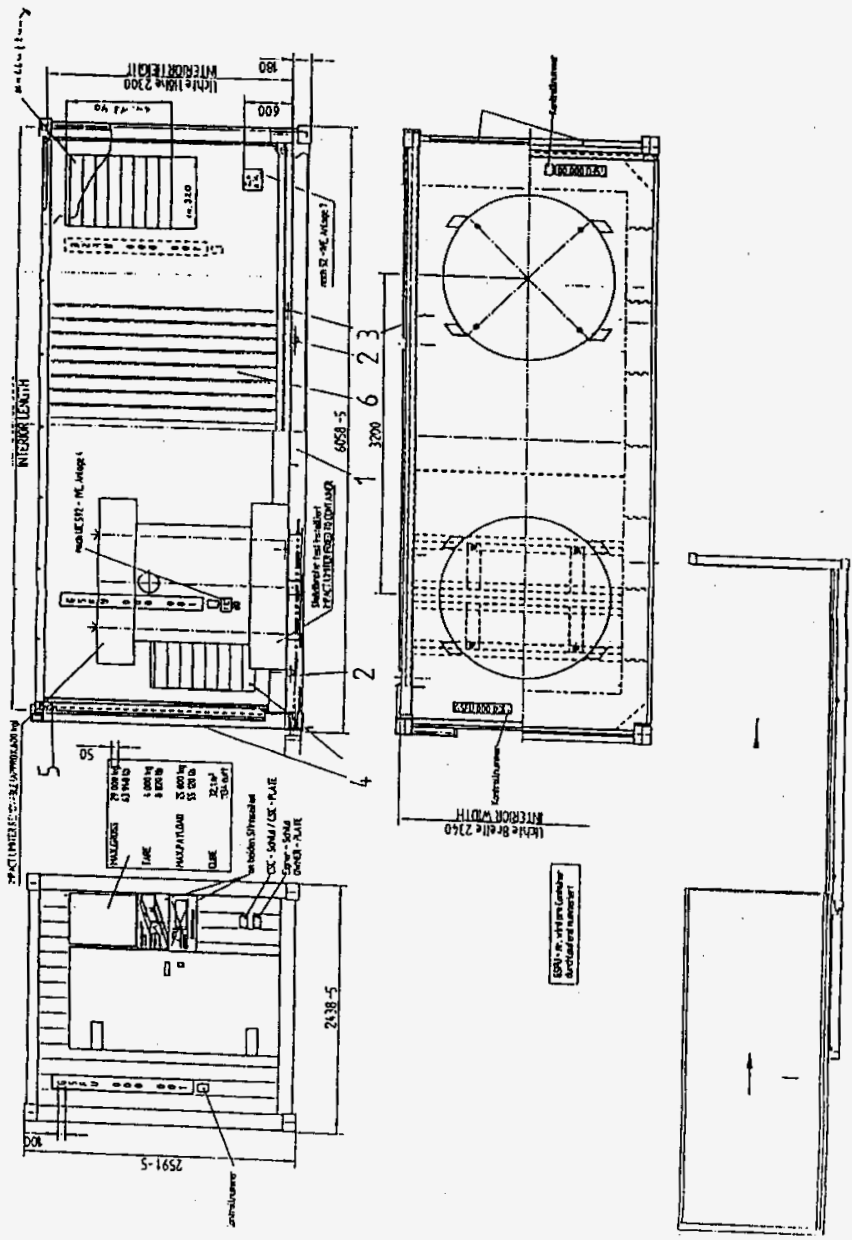

All dimensions in $\mathrm{mm}$. 


\subsubsection{Closure Design and Containment}

Positive closure of the GNS-12 cask is currently achieved through bolting the primary lid to the cask body with 20 cap screws, size M 30 . Currently in the seal surfaces. of the lid, there are two concentric groves to accommodate elastomer seals. The SARP will evaluate the use of WHC and German metallic sea 7 (Helicoflex') designs for the cask primary 1 id inner concentric grooves to meet transport requirements. The elastomeric seals can be of Viton ${ }^{2}$ type for the primary lid outer concentric groove (transportation seal, Figure 6, Numbers 43 and 67). With these, a test volume is defined in the GNS-12 SARP for the leak-tightness test $<1.0 \times 10^{-3} \mathrm{~atm} \mathrm{cc} / \mathrm{s}$, air $\left(<1.0 \times 10^{-3}\right.$ mbar $\left.L / \mathrm{s}\right)$. The most significant sealing action for storage is produced by the inner el astomeric or metallic seal (Figure 6 , Numbers 26, 42, and 66). The SARP will evaluate all three configurations and define any additional design features required to meet Section 4.1 and the acceptance criteria of Section 5.0 defined in this PDC.

Figure 6. Primary Lid Sealing System.

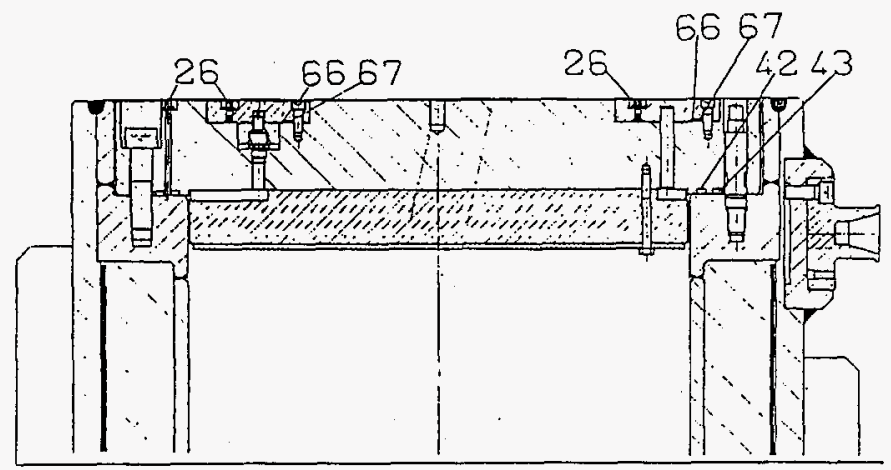

The SARP will evaluate upgrades to the current cask sealing configuration. This evaluation and analys is (where applicable) will determine and authorize the existing seal design and upgrades to the cask primary lid sealing system. The upgrades to the primary lid sealing system allows the combination use of metallic and elastomeric seal configurations for the loaded cask to meet transportation and interim storage requirements. The primary lid seal upgrades shall meet the conditions of Section 5.1, and the acceptance criteria specified in Sections 5.1.1 and 5.1.2 defined in this PDC.

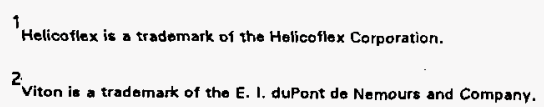




$$
\text { WHC-SD-TP-PDC-033 Rev. } 1
$$

\subsubsection{Shielding}

The GNS-12 cask shielding is designed such that the package general surface dose rate is no greater than a maximum of $200 \mathrm{mR} / \mathrm{h}$ and $10 \mathrm{mR} / \mathrm{h}$ or 1 ess at $1 \mathrm{~m}(3.3 \mathrm{ft})$ from the package.

\subsubsection{Service Life}

For transportation, the assumed cask lifetime is forty years and twenty transports. per year as defined in the GNS-12 SARP.

\subsubsection{Chemical and Galvanic Reactions}

The payload of the GNS-12 cask.will be 1 imited so reactions (e.g., chemical or galvanic reactions) among the components and the cask are minimized.

\subsubsection{Surface Contamination}

Before transfer, contamination on the external surfaces of the GNS-12 cask shall not exceed the limits given in Table 4 .

Table 4. Decontamination Limits.

\begin{tabular}{|l|c|c|}
\hline \multicolumn{1}{|c|}{ Contaminant } & Maximum Permissible Limits \\
\hline \hline $\begin{array}{l}\text { Beta-gamma emitting radionuclides; all radionuclides with half-lives less than } \\
\text { ten days; natural uranium: natural thorium: uranium-235: uranium-238; } \\
\text { thorium-232: tharium-228 and thorium-230 when contained in ores or } \\
\text { physical concantrates }\end{array}$ & $10^{-5}$ & \\
\hline All other alpha omitting radionuclides & & \\
\hline
\end{tabular}

Table from 49 CFR 173.443 .

\subsection{TRANSPORT SYSTEM}

\subsubsection{Transport Vehicle}

The GNS-12 cask shal1 be transported by tractor-trailer or by rail as a closed transport vehicle. The SARP will document the requirements of the transport configurations and any modifications that must be performed to allow for the safe onsite interarea transfer of the cask.

\subsubsection{Tiedowns}

The existing GNS-12 cask securement/tiedown system (Figure 5 ), as described in Section 4.2 .4 , will be evaluated for meeting reasonable onsite transportation. 
WHC-SD-TP-PDC-033 Rev. 1

\subsection{GENERAL REQUIREMENTS}

\subsection{TRANSPORTATION EVALUATION REQUIREMENTS}

The SARP shall evaluate the packaging requirements for the transport of Type B radioactive material as defined by IAEA Safety Series No. 6 (IAEA 1990). Evaluations will be included to address the ability of the altered packaging system to provide containment, shielding, adequate thermal heat dispersal, and a subcritical environment for the vitrified encapsulated material under normal and accident conditions of transport on the Hanford site. The analyses address the new WHC metallic seal design and German lid modifications. All analyses are based on the original GNS-12 SARP.

\subsubsection{Normal Transfer Conditions}

The existing GNS -12 cask design meets IAEA Safety Series No. 6 for norma 1 conditions of transport and has the capacity to retain the payload, limit direct radiation, adequately dissipates thermal heat from the payload, and maintain subcriticality during normal transfer conditions. Design changes described in this PDC shall not change cask performance capabilities as specified in the GNS-12. SARP.

a. Containment. The GNS-12 cask shall prevent the loss or dispersal of the radioactive contents during normal transfer conditions. The payload canister is considered part of the containment system. Containment of the GNS-12 cask shall be maintained to $10^{-6} / A_{2}$ per hour during normal conditions of transport.

b. Shielding. Contents of the GNS-12 cask shall be transported as a full laad (exclusive use). Therefore, the shielding design limits of the GNS-12 cask as designed will Timjt the average accessible contact dose rate to $200 \mathrm{mrem} / \mathrm{h}(0.002 \mathrm{~Sv} / \mathrm{h})$. The dose rate at $6.6 \mathrm{ft}(2 \mathrm{~m})$ from the cask surface shall be limited to $10 \mathrm{mrem} / \mathrm{h}(0.0001 \mathrm{~Sv} / \mathrm{h})$. The dose rate at any normally occupied space in the transfer vehicle shall be limited to less than $2 \mathrm{mrem} / \mathrm{h}$ $(0.00002 \mathrm{~Sv} / \mathrm{h})$. Transport of the casks shall fall under HRCQ exclusive use.

c. Criticality. The amount of fissile material within the GNS-12 cask payload (radioactive nuclides - three canisters) is less than $8.5 \mathrm{~g}$. Consequentiy, subcriticality is maintained for any arrangement of the cask which fall under fissile excepted quantity.

\subsubsection{Accident Events}

a. Containment. The GNS-12 cask shall maintain containment to an $A_{2}$ per week for accident conditions.

b. Shielding. The contents of the packaging shall be limited such that the external dose rate shall not exceed $1 \mathrm{rem} / \mathrm{h}(0.01 \mathrm{~Sv} / \mathrm{h})$ at $3.3 \mathrm{ft}$ (1 $\mathrm{m}$ ) from the surface of the cask. 
WHC-SD-TP-PDC-033 Rev. 1

\subsubsection{Therma?}

The SARP shall verify the maximum thermal payload currently described in the GNS-12 SARP that may be transported in the cask. The maximum thermal heat load shall be limited to ensure the integrity of the cask during normal conditions of transport is not compromised. Additionally, thermal heat dissipation from the cask payload shall be limited so that the maximum exterior temperature of the cask will be less than $180^{\circ} \mathrm{F}\left(82^{\circ} \mathrm{C}\right)$ during the hottest Hanford Site day without considering solar insolation. If required, the SARP will also limit the climatic conditions under which the cask may be transported. Based on the current GNS-12 SARP, gas generation is not a concern.

\subsection{AS LOW AS REASONABLY ACHIEVABLE}

The design features of the GNS-12 cask meet IAEA Safety Series No. 6, and shall be consistent with 10 CFR 71 hypothetical accident conditions for transport and the requirements of the ALARA Program Manual, WHC-CM-4-11. Exposure of personnel to radiological and other hazardous materials associated with the loading, closure, tiedown, transfer, and off-loading of the package shall be minimized.

\subsection{QUALITY ASSURANCE}

Quality Assurance (QA) program requirements for activities such as design, procurement, fabrication, inspection, testing, component handling, and documentation of the GNS-12 cask and their components are specified in the GNS-12 Cask SARP (GNS 1989).

To establish a QA plan for the GNS-12 cask, a graded approach is used to define the safety class of both the system and individual components of the packaging system. The application of the safety class system is fully documented in the Quality Assurance Manual, WHC-CM-4-2. QA instructions or plans shall be developed for the procurement, fabrication, and inspection of the package based on the assigned safety class of the package. The QA Program Plan for the Hazardous Materials Transportation and Packaging Program, WHC-IP-0705 (WHC 1995), and Nonreactor Facilities Safety Analys is Manual, WHC-CM-4-46, defines the WHC QA and safety class implementation, respectively, for radioactive material shipping packages.

\subsubsection{System Safety Class}

The transportation safety class of the GNS-12 cask was determined by a transportation safety class evaluation included in section 6.2. This evaluation assumed the total failure of the packaging system and the release of all of its contents to the environment at the worst possible location on the transportation route. For the shipment of the 324 Building vitrified material, the worst case release location is within the $300 \mathrm{Area}, 330 \mathrm{ft}$ $(100 \mathrm{~m})$ from the release point.

The safety class evaluation guidelines contained in WHC-CM-4-46, Section 9.0, were followed. A worst case event is postulated which results in 
a dose to the maximum onsite and offsite receptor of $13 \mathrm{rem}\left(1.3 \times 10^{-1} \mathrm{SV}\right)$. The onsite and offsite doses are the same because several 300 Area locations have roads which are accessible to the public. The onsite and offsite receptor locations are therefore both assumed to be $100 \mathrm{~m}$ from the release point. Since the maximum offsite dose is greater than $0.5 \mathrm{rem}$, the required Safety Class for the GNS-12 cask is Safety Class 1.

\subsection{DESIGN FORMAT}

Development of the design drawings, design changes, and other design documentation, if required, shall be in accordance with the Standard Engineering Practices, WHC-CM-6-1, and the Drafting Standards manual, WHC-CM-6-3.

\subsection{ENVIRONMENTAL COMPLIANCE}

Actions and conditions for the protection of the environment during transfer of the GNS-12 cask shall comply with the requirements of the Environmental Compliance manual, WHC-CM-7-5.

\subsection{MAINTENANCE}

The maintenance schedule for the cask shall be in accordance with As Low As Reasonabiy Achievable (ALARA) principles and its original SARP GNS B $50 / 87$, Rev. 5 (GNS 1989).

\subsection{REUSE}

The SARP will define guidelines on inspection and maintenance that will allow the cask to be reused in accordance with WHC-CM-2-14 and the original SARP.

\subsection{APPENDICES}

\subsection{REFERENCES}

BAM, 1987, Testing of a Type B(U) Package of Type "GNS 12 Shipping Cask, "File Number 1.5/22141, Copy Number 2, German Federal Materials Testing Institute (BAM) Test Certificate, November 5, 1987.

GNS, 1989, Safety Analysis Report for the GNS-12 Shipping Cask, GNS B 50/87, Rev. 5, Gesellschaft für Nuklear-Service mbH, Essen., Federal Republic of Germany, October 1989.

GNS, 1990, Safety Analysis Report CASTOR GSF, GNS B 69/85, Rev. 10, Gesellschaft für Nuklear-Service mbH, Essen., Federal Republic of Germany, July 1990. 
IAEA, 1990, Regulations for the Safe Transport of Radioactive Material 1985 Edition, IAEA Safety Series No. 6, as amended 1990, International Atomic Energy Agency, Vienna, Austria.

NRC, 1984, NRC IE Information Notice 84-72, U.S. Nuclear Regulatory Commission, Washington, D.C., September 10, 1984.

PTB, 1990, Certificate of Approval for the GNS-12 Shipping Cask, German Federal Physical-Technical Institution (PTB), Braunschweig D/2065/B(U) Rev. 2, February 7, 1990.

RL, 1994, Hanford Site Radiological Control Manual, HSRCM-1, U.S. Department of Energy, Richland Operations Office, Richland, Washington.

WHC-CM-2-14, Hazardous Material Packaging and Shipping, Westinghouse Hanford Company, Richland, Washington.

WHC-CM-4-2, Quality Assurance Manual, Westinghouse Hanford Company, Richland, Washington.

WHC-CM-4-11, ALARA Program Manual, Westinghouse Hanford Company, Richland, Washington.

WHC-CM-4-46, Nonreactor Facility Safety Ana7ysis Manual, Westinghouse Hanford Company, Richland, Washington.

WHC-CM-6-1, Standard Engineering Practices, Westinghouse Hanford Company, Richland, Washington.

WHC-CM-6-3, Drafting Standards, Westinghouse Hanford Company, Richland, Washington.

WHC-CM-7-5, Environmental Comp $7 i$ ance, Westinghouse Hanford Company, Richland, Washington.

WHC, 1993, Hanford Solid Waste Acceptance Criteria, WHC-EP-0063, Westinghouse Hanford Company, Richland, Washington.

WHC, 1995, QA Program for the Hazardous Materials Transportation and Packaging Program, WHC-IP-0705, Rev. 1, Westinghouse Hanford Company, Richland, Washington. 
WHC-SD-TP-PDC-033 Rev. 1

6.2 SAFETY CLASS EVALUATION 
ENGINEERING ANALYSIS

SUbject TRANSPORTATION SAFETY CLASS EVALUATION FOR GNS-12 CASK

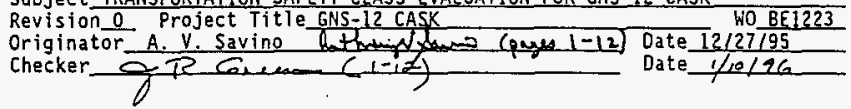

\section{Objectives:}

This engineering analysis documents a transportation safety class evaluation for the GNS-12 Cask which will be used to transport canisters containing activated vitrified glass material from the 324 Building in the 300 Area to the 200 West Area.

\section{References:}

60 FR 50319, 1995, "Hazardous Materials, Transportation Regulations; Compatibility With Regulations of the International Atomic Energy Agency (IAEA); Final Rule," 49 CFR Part 171, Federal Register, Vol. 60, No. 188, pp. 50319-50325.

DOE, 1994, Airborne ReIease Fractions/Rates and Respirable Fractions for Nonreactor Nuclear Facilities, DOE-HDBK-3010-94, U. S. Department of Energy, Washington, D. C.

Hey, B. E., 1995a, GXQ 4.0 Progran Users' Guide, WHC-SO-GN-SWO-30002, Rev. 1, Westinghouse Hanford Company, Richland, Washington.

Hey, B. E., 1995b, GXQ 4.0 Progran Verification and Validation, WHC-SO-GN-SWD-30003, Rey. 1, Westinghouse Hanford Company, Richland, Washington.

Napier, B. A., et al., December 1988, GENII - The Hanford Environmental Radiation Dosimetry Software Systen, Pacific Northwest Laboratory, Richiand, Washington, PNL-6584 Vol. 1, UC-600.

NRC, 1982, Atmospheric Dispersion Models for Potential Accident Consequence Assessments at Nuclear Power Plants, Regulatory Guide 1.145, U.S. Nuclear Regulatory Comission, Washington, D.C.

Schinittroth, 1993, Conversion of ORIGEN2 to Sun Workstations, WHC-SD-NR-SWD006 Rev. 0-A, Westinghouse Hanford Company, Richland, Washington.

WHC-CM-4-46, Nonreactor Facility Safety Analysis Manual, Westinghouse Hanford Company, Richland, Washington.

\section{Results and Conclusions:}

The safety class evaluation guidelines contained in WHC-CM-4-46, Section 9 , were followed. A worst case event is postulated which results in a dose to the maximum onsite and offsite receptor of 13 rem $\left(1.3 \times 10^{-1} 5 \mathrm{~V}\right)$. The onsite 
WHC-SD-TP-PDC-033 Rev. 1

ENGINEERING ANALYSIS

Subject TRANSPORTATION SAFETY CLASS EVALUATION FOR GNS- 12 CASK Revision 0 Project Tit]e GNS-12 CASK

originator A.V. Savino dND

checker

Ira

Date $12 / 27 / 95$

HO BE. 223

Date $1 / 10 / 96$

and offsite doses are the same because several 300 Area locations have roads which are accessible to the public. The onsite and offsite receptor locations are therefore both assumed to ba $100 \mathrm{~m}$ from the release point. Since the maximum offsite dose is greater than 0.5 renin, the required transportation safety class for the GNS-12 cask is transportation safety class 1 .

\section{Engineering Evaluation:}

\subsection{Introduction}

The GNS-12 cask is designed to hold three activated glass canisters. A glass canister is a container with vitrified radioactive materials manufactured at Hanford. These casks will be transported from the 300 Area to the 200 West Area. An evaluation is necessary to determine the required transportation safety class for the cask.

\subsection{Source Term}

Table 1 lists the source term for the GNS-12 cask which was developed in Section 2 of the POC. 
WHC-SD-TP-PDC-033 Rev. 1

ENGINEERING ANALYSIS

SUbject TRANSPORTATION SAFETY CLASS EVALUATION FOR GNS-12 CASK Revision 0 Project Title GNS-12 CASK Originator_A. V. Savino Checker

\begin{tabular}{|c|c|c|}
\hline Nuclide & $\begin{array}{c}\text { single eanister } \\
\text { h=tivity, } \mathrm{Ci}\end{array}$ & $\begin{array}{l}\text { Maximum Cask } \\
\text { Aztivisy, } \mathrm{Ci}^{\mathrm{a}}\end{array}$ \\
\hline $5 R 90$ & $2.1 E=0.5$ & $6.3 E+05$ \\
\hline$r 90$ & $2.1 E+05$ & $6.3 E+05$ \\
\hline $\operatorname{cs} 137$ & $3.05+05$ & $9.05+05$ \\
\hline BA137 & $2,8 E+05$ & $0.45+05$ \\
\hline TL208 & $1.25-04$ & $3.65+04$ \\
\hline P32:2 & $3.3 \notin \cdot 06$ & $9.95-04$ \\
\hline 51212 & $3.3 E-04$ & 9.95 .06 \\
\hline POZ12 & $2.15 \cdot 06$ & $6.3 E .06$ \\
\hline POzIs & $3.3 \pm-06$ & 9.95 .04 \\
\hline RN2ZO & $3.3 \equiv-06$ & 9.95 .06 \\
\hline RA224 & $3.3 E+04$ & $9.9 E \cdot 06$ \\
\hline$R \times 223$ & $3.3 \mathrm{E}-04$ & $9.9 E-06$ \\
\hline$A C 228$ & $3.3 \pm .04$ & 9.95 .06 \\
\hline TH228 & $3.3 \pm-06$ & $9.95 \cdot 04$ \\
\hline TH231 & $1.9 E-07$ & $5.7 \pm-07$ \\
\hline TH232 & $3.3 \equiv .06$ & $9.95-06$ \\
\hline ГH 234 & $3.4 E \cdot 0.6$ & $1.0 \equiv-05$ \\
\hline PA23: & $3.45 \cdot 06$ & $1.05-05$ \\
\hline v234 & 5.35 .06 & 1.65 .05 \\
\hline 4235 & $1.9 \pm-07$ & $5.7 \mathrm{E} \cdot 07$ \\
\hline U236 & 4.45 .07 & $1.3 \hat{e} \cdot 06$ \\
\hline v237 & $5.5 E \cdot 0.5$ & 1.75 .04 \\
\hline U233 & $3.4 E-08$ & 1.05 .05 \\
\hline HP239 & $2.05-01$ & 0.05 .01 \\
\hline PU238 & $1.7 \varepsilon \cdot 01$ & $5.1 \equiv-01$ \\
\hline Pu239. & $1.73-01$ & $5.1 \mathrm{E} \cdot 01$ \\
\hline PU2:0 & $5.6 \mathrm{E} \cdot 02$ & $1.7 \AA .01$ \\
\hline pu2-1 & $2.3 E+00$ & $8.95+00$ \\
\hline PU262 & $4.6 E-05$ & $1.6 E-0 \%$ \\
\hline $\operatorname{AM} 241$ & $3.45-01$ & $1.05+\infty 0$ \\
\hline$A 4263$ & 2.05 .01 & $6.0 E-01$ \\
\hline TOTALS & 1. $0 E+06$ & $3.05+06$ \\
\hline
\end{tabular}

assumes a maximum of 3 canisters will be laaded in the Gis-12 cask. 
ENGINEERING ANALYSIS

SUbject TRANSPORTATION SAFETY CLASS EVALUATION FOR GNS-12 CASK Revision $\frac{D}{\text { Project TitTe GNS-12 CASK }}$ Originator A. V. Saving thecker

I Date $12127 \frac{85}{195}$ WO BE1223 Date -110196

\subsection{Analysis}

The safety class evaluation quidelines contained in WHC-CM-4-45, Section 9, were followed. A worst casa airborne release fraction was determined based on a review of the potential accident scenarios which the package may experience.

The ARF and RF were calculated using a formula contained in DOE (1994), Free-Fall Spill and Impaction Stress for Nonmetallic or Composite Solids. This formula is associated with "fragmentation of an aggregate solid that can undergo brittle fraction." It is assumed for this analysis that an event occurs where the package is breached by an external force causing the vitrified material to be released and inpact tha ground. This impact causes fragmentation of the material at risk and subsequent release to the enviroment. The formula given is as follows:

$$
A R F \times R F=(A)(P)(g)(h)
$$

where:

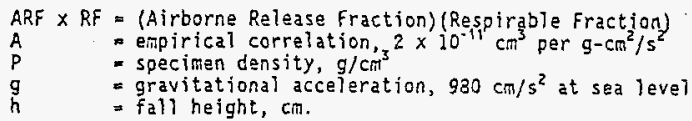

A fall height of $1 \mathrm{~m}$ is assumed for this analysis. This is a typical height used for objects falling off of a truck. The density of the waste is $2.8 \mathrm{~g} / \mathrm{CC}$, which results in an ARF $\times$ RF of $5.5 \times 10^{-5}$. This ARF $\times$ RF is applied to the material at risk, which is conservatively assumed to be the entire cask inventory, to obtain the quantity of radioactive material that is made airborne for the postulated accident scenario. The accident release quantities are listed in Table 2.

A fire scenario was aiso considered, but based on information contained in DOE (1994), Thermal Stress - Vitrified Waste (Section 4.3.1.1), "any release under industrial-type fire conditions appears to be negligible." Therefore, no airborne release fire scenario is included in this analysis. 
WHC-SD-TP-PDC-033 Rev. 1

ENGINEERING ANALYSIS

Subject TRANSPORTATION SAFETY CLASS EVALUATION FOR GNS-12 CASK Revision 0 Project Title GHS-12 CASK

Originator A. V. Savino AVS

WO BE1223

Checker

Fec

Date $12 / 27 / 95$

Date $\sqrt{10 / 46}$

\begin{tabular}{|c|c|c|}
\hline Nuelide & $\begin{array}{l}\text { Maximun Casix } \\
\text { Aesivisy, Cia }\end{array}$ & $\begin{array}{l}\text { Accident Relegse } \\
\text { Guantity, Cl }\end{array}$ \\
\hline 5290 & $6.35+05$ & $3.55+00$ \\
\hline Y90 & $6.35+05$ & $3.55+00$ \\
\hline cs 137 & $9.0 \varepsilon+05$ & $5.0 \varepsilon+00$ \\
\hline BA137m & 8. $62 \div 05$ & $6.6 \mathrm{E}+00$ \\
\hline ILEOS & $3,6 E-04$ & $2.0 \bar{E}-09$ \\
\hline PB212 & $9.95-04$ & 5.65 .09 \\
\hline$B 1212$ & $9.95-04$ & $5,45-09$ \\
\hline PO212 & 5.3E-04 & $3.5 E-09$ \\
\hline P0216 & $9.95-06$ & $5.45-09$ \\
\hline RE220 & $9.95-04$ & $5.65-09$ \\
\hline RA224 & $9.95-05$ & $5.45-09$ \\
\hline $8 \times 228$ & $9.95-04$ & $5.4 E \cdot 09$ \\
\hline AC228 & $9.9 E-04$ & $5.45-09$ \\
\hline TH2?S & $9.9 E-02$ & $5.65-09$ \\
\hline 14231 & $5.7 \xi-07$ & 3. $1:-12$ \\
\hline 74252 & $9.9 E-06$ & $5.4 \equiv-09$ \\
\hline in:234 & $1.0 \mathrm{E}-05$ & $5.5 \equiv-11$ \\
\hline PA23in & $1,0 E-05$ & $5.5 E-11$ \\
\hline U23: & $1.6=05$ & $8.2 \overline{5} \cdot 11$ \\
\hline U235 & 5.75 .07 & $3.1 \mathrm{E}-12$ \\
\hline ט236 & $1+35-05$ & $7.25-12$ \\
\hline บ237 & $1.7 E-C G$ & $9.6 \equiv-10$ \\
\hline U238 & $1.0 E-05$ & $5.5 E-11$ \\
\hline KP 239 & $6.0 E-01$ & $3.3 E \cdot 06$ \\
\hline PU238 & $5.1 \equiv-01$ & $2.8 E \cdot 05$ \\
\hline Pu237 & $5.1 \mathrm{E}-01$ & $2+8 E-06$ \\
\hline PU2:0 & $1.7 \bar{c}-01$ & $9.4 E-07$ \\
\hline$P \cup 2 \div 1$ & $6.5 E+00$ & $3.8 \mathrm{~g} .05$ \\
\hline PU2:2 & $1.45-02$ & $7.7 \pm \cdot 10$ \\
\hline$A 4241$ & $1.0 E+00$ & $5.5 \leq-0.5$ \\
\hline$A 4263$ & $6.05 \cdot 01$ & $3.3 \pm-06$ \\
\hline TOPALS & 3. $0 E+06$ & $1.7 \pm+01$ \\
\hline
\end{tabular}

assumes maximum of 3 eanisters will be loased in the GNS. 12 cask.

Calculaced usirgothe maximn cask activities from colum I and applying the ARF $x$ RF value of $5.5 \times 10^{\circ}$ to all radionuclides.

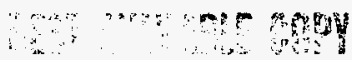


WHC-SD-TP-PDC-033 Rev. 1

ENGINEERING ANALYSIS

SUbject TRANSPORTATION SAFETY CLASS EVALUATION FOR GNS-I? CASK Revision 0 Project Tithe GNS-12 CASK

Originator A.V. Savino NAS

Checker

Iers

Date $12 / 27 / 95$

WO BE 1223

oate 1110196

\section{Discussion of Atmospheric Relative Concentration Value $\left(y / 0^{\prime}\right)$}

After the radioactive material becomes airborne, it is transported downind and inhaled by onsite workers or the public. The concentration of this material is reduced, or diluted, as it is being transported due to atmospheric mixing and turbulence. An atmospheric relative concentration value $\left(X / Q^{\prime}\right)$ is used to characterize the dilution of the airborne contaminants during atmospheric transport and dispersion. It is equal to the timeintegrated normalized air concentration at the receptor. $x / Q^{1}\left(5 / \mathrm{m}^{3}\right)$ represents the dilution of an airborne contaminant caused by atmospheric mixing and turbulence. $X / Q^{\prime}$ is a function of the atmospheric conditions (i.e., wind speed, stability class) and the distance to the receptor.

Bounding $X / Q^{\prime}$ values are generated consistent with the methods described in Atmospheric Dispersion Models for Potential Accident Consequence

Assessments at Huclear Power Flants, Regulatory Guide 1.145 (NRC 1982). Since atmospheric conditions fluctuate, a bounding atmospheric condition is determined to be that condition that causes a downwind concentration of airborne contaminants that is excesded only a small fraction of time because of weather fluctuations. Regulatory Guide 1.145 defines this fraction of exceedance as $0.5 \%$ for each sector or $5 \%$ for the overall Hanford Site. The Hanford Site is broken up into 15 sectors that represent 16 compass directions (i.e., $S, S S W, S H, \ldots$, ESE, SE, SSE). $x / Q^{\prime}$ values are generated for weather conditions that result in downind concentrations exceeded only $0.5 \%$ of the time in the maximum sector or 5\% of the time for the overall site. These $x / Q^{\prime}$ values are also referred to as $99.5 \%$ maximum sector and $95 \%$ overail $S i t e x / Q^{\prime}$ values. The greater of these two values is called the bounding $X / Q^{\circ}$ value and is used to assess the dose consequences for accident scenarios. The bounding $X / Q^{\prime}$ value represents minimum dispersing conditions that result in maximum downwind concentrations (i.e., concentrations exceeded only a very small fraction of the time). This $X / Q^{\prime}$ value will therefore result in very conservative estimates of accident consequences.

The $X / Q^{\prime}$ values in this report were generated using the GXQ computer program, Version 4 (Hey 1995a, 1995b). The meteorological data used by $6 \times Q$ are in the form of joint frequency tables. The joint frequency data are the most recent data available; they are nine-year averaged data $(1983-1991)$ from the Hanford Site meteorology towers. As mentioned above, the $x / Q^{\prime}$ values are generated using the methods described in Regulatory Guide 1.145 for a ground release with no credit taken for plume rise, plume meander, plume depletion, or any other models. This is conservative because all of these models reduce the airborne concentration at the downwind receptor locations. 
WHC-SD-TP-PDC-033 Rev. 1

ENGINEERING ANALYSIS

Subject TRANSPORTATION SAFETY CLASS EVALUATION FOR GNS-12 CASK Revision 0 Project Title GNS-12 CASK

Originator A.V. Savino Alt

checker

26

Date_12/27/95

WO BE1223

Date. 140196

The GNS-12 packages will be transported from the 300 Area to the 200 Area. Therefore, $X / Q^{\prime}$ values for the maximum onsite receptor (assumed to be located $100 \mathrm{~m}$ from the release point) were calculated using the joint frequency data for these two areas (i.e., 200, 300 Areas), and the highest value was selected. The highest $x / Q$ ' value of $4.2 \times 10^{-2} \mathrm{~s} / \mathrm{m}^{3}$ occurs for the 300 Area.

The worst case offsite receptor (i.e., highest $x / Q^{\prime}$ ) will be located in the 300 Area due to the short distances between the potential transport routes and an offsite receptor. Several 300 Area locations have roads which are accessible to the public. It is conservatively assumed for this analysis that the offsite receptor is located 100 m from the release point in any compass direction. The maximum onsite and offsite receptor $X / Q$ ' value will therefore be the same, and since the highest $\chi / Q^{\prime}$ occurs for the 300 area, the maximum offsite $x / Q^{\prime}$ value is $4.2 \times 10^{-2} \mathrm{~s} / \mathrm{m}^{3}$. The titles of the joint frequency files used by GXQ are listed below.

200 AREA (HMS) - $10 M$ - Pasquill A - G (1983 - 1991 Average)

300 AREA - 10 M - Pasquill A - G (1983 - 1991 Average)

\section{Inhalation \& Submersion Dose Calculations}

The GENII computer code Version 1.485 (Napier 1988) was used to calculate the inhalation and submersion dose for the maximum onsite and offsite receptors using the $X / Q^{\prime}$ value mentioned in the previous paragraph. The GENII input deck is listed in Attachment 1. The "Worst Case" solubility class library in GENII was selected since the form of the radioactive material is not known with a high degree of certainty. This solubility class is the most conservative library used in GENII. The GENII libraries used were as follows:

GENII Default Parameter Values (28-Mar-90 RAP)

Radionuclide Library - Times 100 years (23-July-93 PDR)

External Dose Factors for GENII in person Sv/yr per $\mathrm{Eq} / \mathrm{n}(8-\mathrm{May}-90$

Worst-Case Solubilities, Yearly Dose Increments (23-Jul-93 PDR)

The Effective Dose Equivalent (EDE) for the inhalation and submersion pathways is 13 rem $\left(1.3 \times 10^{-1}\right.$ Sv) for the maximum onsite and of receptors at $100 \mathrm{~m}$. The inhalation dose contribution to the EDE is based on a 50 year dose commitment period. Table 3 sumarizes the results. Note that ${ }^{90} \mathrm{Sr} /{ }^{90} \mathrm{Y}$ contribute $82 \%$ to the total dose, and ${ }^{137} \mathrm{Cs}$ contributes $17 \%$ to the total dose. 
WHC-SD-TP-PDC-033 ReV. 1

ENGINEERING ANALYSIS

SUbject TRANSPORTATION SAFETY CLASS EVALUATION FOR GNS- 12 CASK

Revision 0 Project Title GNS-1? CASK

Originator A. V. Savino AdS

Checker

IRG

Date $12 / 27195$

Date $\frac{12 / 27 / 95}{1 / 10 / 46}$

\begin{tabular}{|l|r|r|}
\hline \multicolumn{3}{|c|}{ Table 3: Summary of Inhalation and Submersion Dose, rem } \\
\hline \multirow{2}{*}{ Whole Body EDE } & $\begin{array}{r}\text { Maximum Onsite } \\
\text { Receptor at } 100 \mathrm{~m}\end{array}$ & $\begin{array}{c}\text { Maximum Offsite } \\
\text { Receptor at } 100 \mathrm{~m}\end{array}$ \\
\cline { 2 - 4 } & 13 & 13 \\
\hline
\end{tabular}

Note: 100 ren $=1 \mathrm{SV}$

\subsection{Conclusion}

The maximum offsite dose of 13 rea $\left(1.3 \times 10^{-1} \mathrm{SV}\right)$ is greater than 0.5 rem. Therefore, the required transportation safety class for the GNS-12 cask is transportation safety class 1. 
WHC-SD-TP-PDC-033 Rev. 1

ENGINEERING ANALYSIS

SUbJect TRANSPORTATION SAFETY CLASS EVALUATION FOR GNS-12 CASK Revision 0 Project Title GNS-12 CASK

originator A. $V$. Savino NV

Checker

IQR

Date $12 / 27 / 95$

WO BE1223

Date $1 / 10 / 96$

\section{Attachment I}

\section{GENII INPUT FILE}

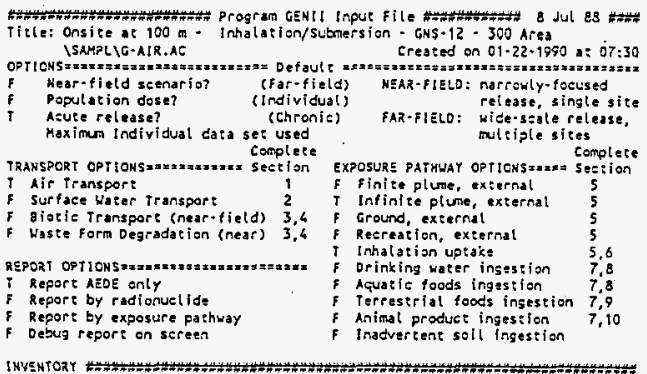

4 Inventory input activity units: (1-pei 2-uci 3-nci 4-ci 5-3q)

- Surface sail source units $\left(1 \cdot \mathrm{m}_{2} \quad 2 \cdot \mathrm{m}^{3} 3 \cdot \mathrm{k} \cdot \mathrm{k}\right)$

Equilibrim question sees here

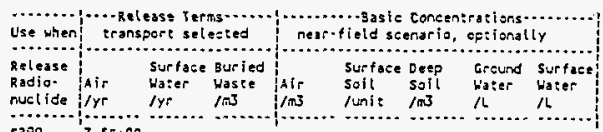

$5290 \quad 3,5 \mathrm{E}+00$

$\times 90 \quad 3.5 \overline{2}+00$

CS137 $5.0 E+00$

P3212 $5.6 E+09$

B. $1212 \quad 5.4 E-09$

QA225 5.4E-09

RA22S $5.4 E-09$

AC228 . 5.45-09

TH1228 S.6E-09

TH231 3.1E-12

TH232 5.4E-OP

TH234 5.5E-11

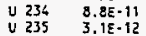

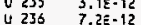

U 257 9.6E-10

U $238 \quad 5.5 E-11$

HP 239 3.3E-O6

PU235 2.8E-06

PU239 $2.85-06$

PUZ20 9.4E-07

PU261 3.8E-05 
WHC-SD-TP-PDC-033 Rev. 1

ENGINEERING ANALYSIS

Subject TRANSPORTATION SAFETY CLASS EVALUATION FOR GNS-12 CASK Revision 0 Project Title GNS-12 CASK

originator A.V. Savino AV Checker $\pm 26$

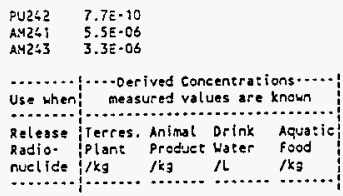

TIME

1 Intake ends after (yt)

So Dose calc. ends at ther (yr)

i Release ends after (ye)

- No. of years of air Eeposition prior to the intake perfod

0 No. of yesrs of irrigation wacer deposition prior to the intake period

FAR-FIELD SCENARLOS (IF POPULATION DOSE)

a Definition eptien: 1-Use populatien grid in file pos.tH

2 -Use total entered on this line

NEAR-FIELO SCEMARIOS

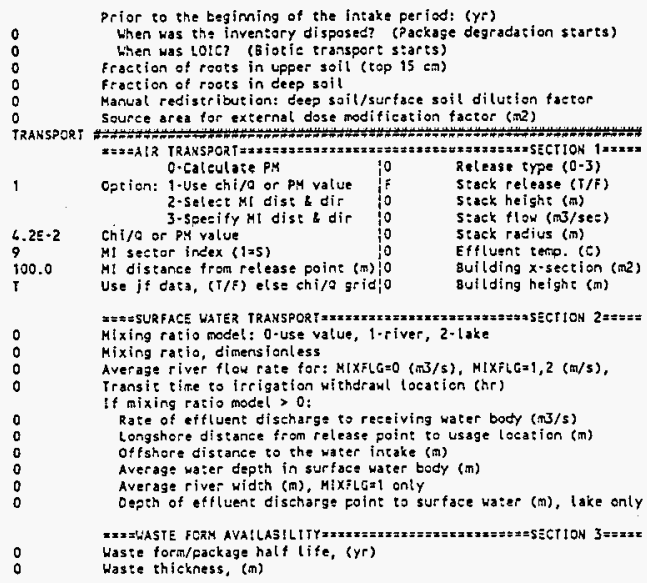


Hog J J

II

\begin{tabular}{|c|c|c|c|c|c|c|c|c|}
\hline $\begin{array}{l}0.0 \\
0.0 \\
0.0 \\
0.0\end{array}$ & $\begin{array}{l}0.0 \\
0.0 \\
0.0 \\
0.0\end{array}$ & $\begin{array}{l}00+30.0 \\
00+30.0 \\
00+30.0 \\
00+20.0\end{array}$ & $\begin{array}{l}0.0 \\
0.0 \\
0.0\end{array}$ & $\begin{array}{l}0.0 \\
0.0 \\
0.0 \\
0.0\end{array}$ & $\begin{array}{l}0.0 \\
0.0 \\
0.0 \\
0.0\end{array}$ & $\begin{array}{l}0 \\
0 \\
0\end{array}$ & $\begin{array}{l}00 \% 0 \\
00^{\circ} 0 \\
00.0 \\
00.0\end{array}$ & 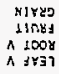 \\
\hline$\ldots$ & $\ldots \ldots$ & ...... & $\cdots$ & $\because \cdots$ & . & & $\ldots$ & $\ldots \ldots$ \\
\hline ED & dก0? & $\begin{array}{l}\text { Nolion } \\
.0084\end{array}$ & $0731 k$ & $\begin{array}{l}\text { EnI } \\
\therefore \text { NO }\end{array}$ & \#2Y & & $\begin{array}{r}\text { EP } \\
\vdots h i 11 \\
\text { gods }\end{array}$ & $\begin{array}{l}3+11 \\
0001\end{array}$ \\
\hline
\end{tabular}

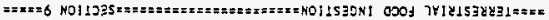

\begin{tabular}{|c|c|c|c|c|c|c|}
\hline 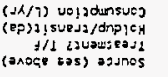 & $\begin{array}{l}0 \\
0 \\
1 \\
0\end{array}$ & $\begin{array}{l}0.0 \\
0.0 \\
0.0 \\
0.0\end{array}$ & $\begin{array}{l}00.0 \\
00.0 \\
00.0 \\
00.0\end{array}$ & $\begin{array}{l}00+30^{\circ} 0 \\
00+30^{\circ} 0 \\
00+30^{\circ} 0 \\
00+30^{\circ} 0\end{array}$ & $\begin{array}{l}00^{\circ} 0 \\
00^{\circ} 0 \\
00^{\circ} 0 \\
00^{\circ} 0\end{array}$ & 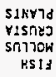 \\
\hline घgirn onixhivo & & $\begin{array}{l}15 / 5 x \\
3+54 \\
\text { NOIISA }\end{array}$ & 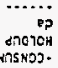 & $\begin{array}{r}J K / E x \\
\text { NoI } \perp \partial n \\
\text { - OOYd }\end{array}$ & $\begin{array}{r}\text { J4 } \\
\text { IIS } \\
-N \in 2 !\end{array}$ & 3e11 \\
\hline
\end{tabular}

(4iszy s! zinefop) bajen ajes

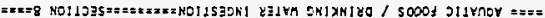
anoge pasaiva noljejzuajuoj pan!jag-e

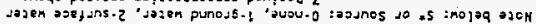

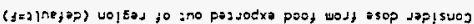

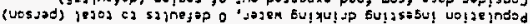

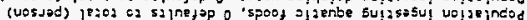

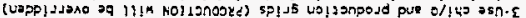
vel sonpojed wjogitun =\$n.-2

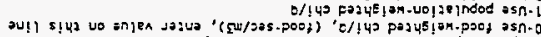

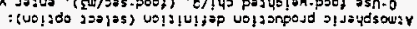

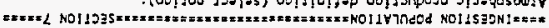

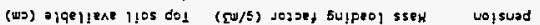

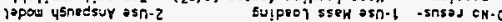

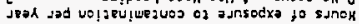

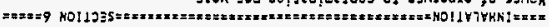

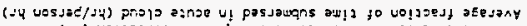

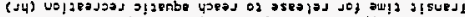

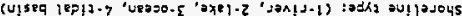
(jk/ON) uoljesno

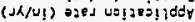

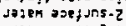

sajex puness-1 :osmos (3/1) : i (s) 2013 inisos (JW) BU, 2808 (ju) Eutuntms

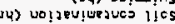
(ग) surid

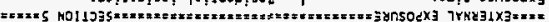

1

je Jnains!ater-5 |

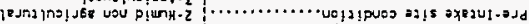

jesni i(d/1) polded dinplime/cesep Ajozuenul Gujung jepisuoj

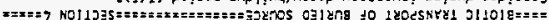

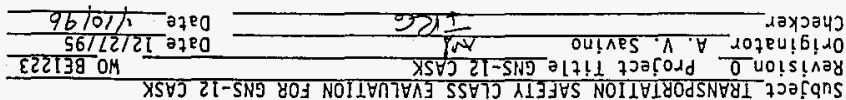

SIS 
WHC-SD-TP-PDC-033 Rev. I

ENGINEERING ANALYSIS

SUbject TRANSPORTATION SAFETY CLASS EVALUATION FOR GNS-12 CASK Revisiono Project Title GNS-12 CASK

Originator A. V. Savino N N

WO BE1223

Checker

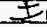

Date $12 / 27 / 95$

Date $\frac{1 / 10496}{160}$

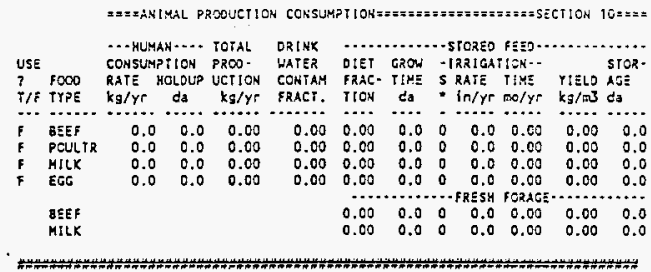


WHC-SD-TP-PDC-033 Rev. I

\subsection{COMPETENT AUTHORITY}


WHC-SD-TP-PDC-033 Rev. 1

$-$

9

USteogriner. al irsuszarcion

Roseorch and

Spreicl piscrems Administretion

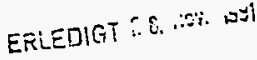

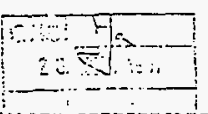

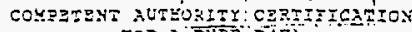

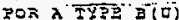

RADTOACTIVZ YATERIAIS FXCLREZ DZITGM

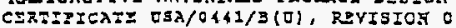

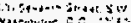

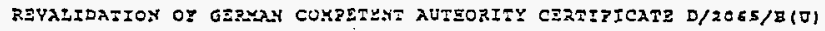

ra1s certities that the radicactive aterials package dasign ccocribed belcs is hereby aupzoved roz vse within the United

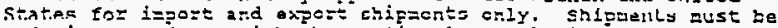
wale in accordance vith the applicable regilations of the

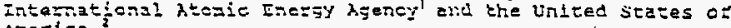
$\cdots$ Ánelica.

1. Dackace ILentieication - ctis 12.

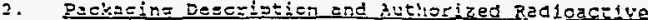
contents as desezibed in Gasan certifieate of Cospetent Authosity D/2065/B(U), Rev. O (atteched).

3. General conglifiens -

a. Fach user of this caztitica:o fust have in his poryession a cogy of chis cerclifcate and all docuente recessary to pzeperly yievere tha package tor transpartatien in aceezance with the crdozsed castilicale.

b. Iach usez of this eerrizlcate, other than the original petitioner, shall register his identity in yiting to the office of Hazazdeus fateri=ls Technolugy, (DKY-23), Research and special frograss A 1 inistration, U. $z$. Eepaztrient $u E$ rransportation, wasuington, D.C. 20590-0001.

c. Inis certificate coes not zoliove any consigno= o: carfier lrou conpliance wien any zequiramant of the covezroont of any countiy thectigh or into which the gackage is to be transported.

1 "Safcty gezics No. $C$, Regulatiuns zor the sate Transport or kadloactive Katerials, 1973 Edition" Fiblistcd by the Internationel Atorle Enesy rgency (IAEd), Vlenra, Austria.

2 Iitle 49, code of Feceral Ragulations, pazts $100-199$ $\smile$ United states of Aferica.

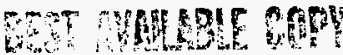


WHC-SD-TP-PDC-033 Rev. I

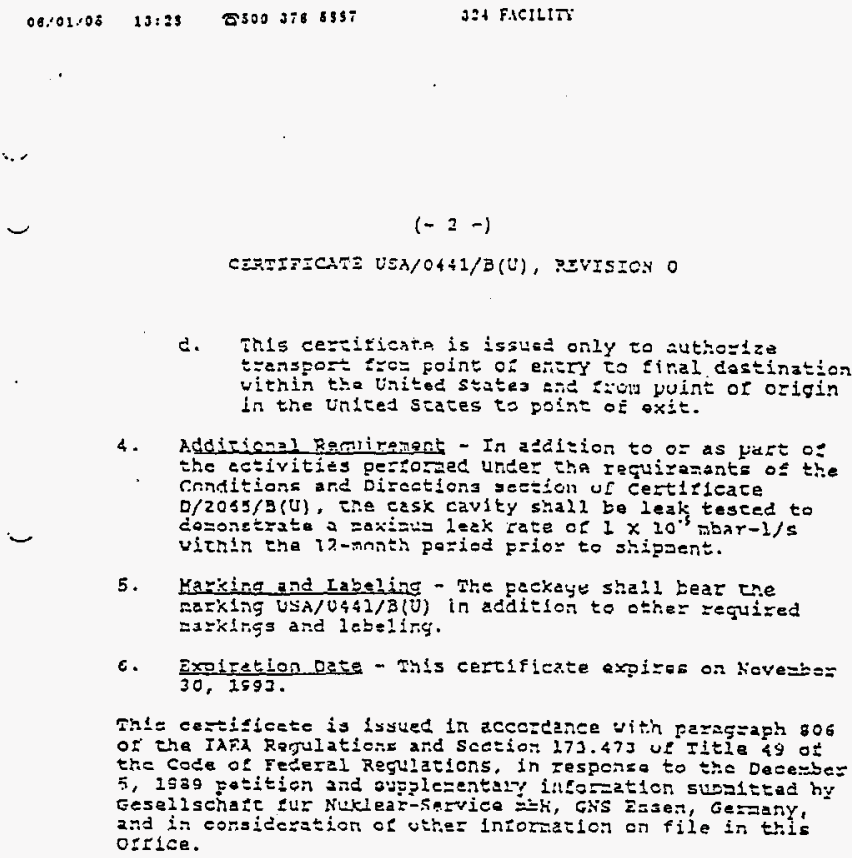

4. Addicienal Reariteinent - In ascilion to of as vaft of the ectivities pertonded under tha requiremants of the Crnditions ard Dircctions yezion uf certirleare $0 / 2055 / 3(U)$, ene cask cavity shall to leak teseed to do=one zrate a vaxizin leek rete of $1 \times 10^{3}$ mbar-1/s vithin the id-nanth pojiod frior to shipjent.

5. Harking and lakeling - The packayt sha11 bear the merking USA/U441/3(U) in addition to other reguifed alukings and lebeling.

c. Expifetion Dete - Tyls cercificate expizes on kovejis= $30,2593$.

This cerificete is lsyued in accordaneg with parsg=2gh 806 of the IAFl Regulaticnx and Scesion $271.47 \mathrm{~J}$ uf Iitie 49 of the Code of Federal Reçulations, in zesponse to the Deceuter

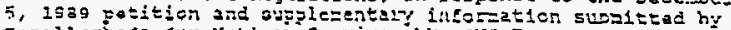

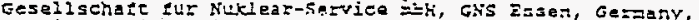
and in consilezation or uther inrornetion on file in tris ortice.

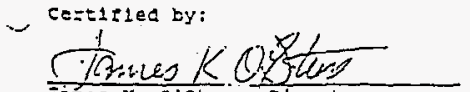

Nov 221991

jises K. O'stech Dizecto:

olflce of Hezardous Materizls Techrology 
WHC-SD-TP-PDC-033 ReV. 1

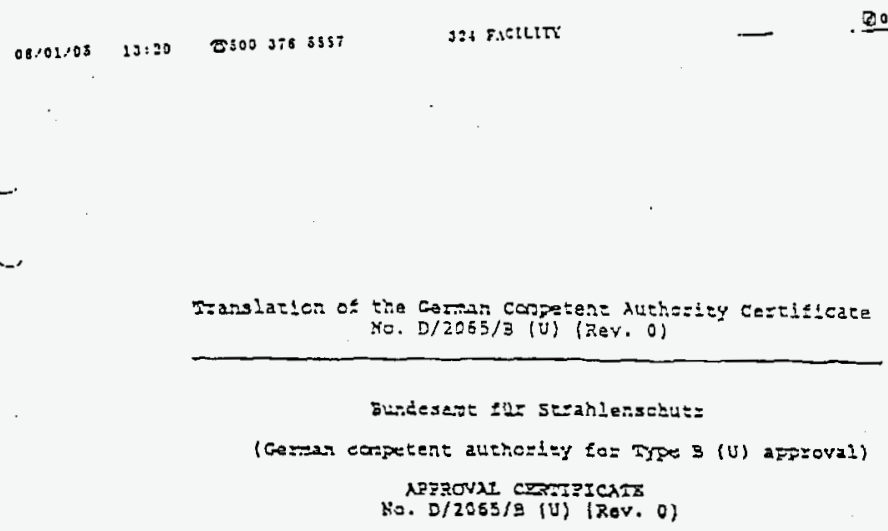

APFEOUI CEREIZICATS

Ho. $D / 2055 / 9$ (U) (R०V. 0 )

Rollewisg the application of the corany Gis Gesollschete fir-

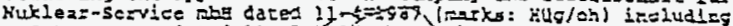
salety report dated i1-13-719,5 the clsk wits ranufacturex's

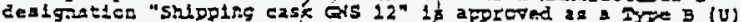
package dastga for Tedicactiva natorials occording to the regrlarian:

Regulatisin to: the sate Irasport of Redioective Materials,

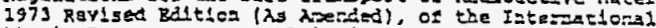

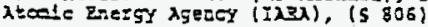

(cerran) Regulationa for the Dorestic and Isterational Tranzporeation of Dargerous coods en hoads

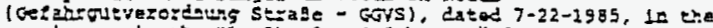

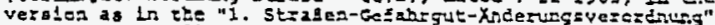

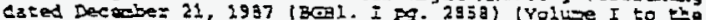

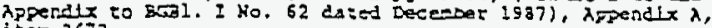
ites 3672

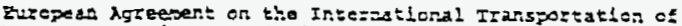

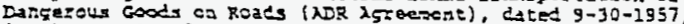
in the verston dated 7-22-1985 (5001. I f5. 1550), Appendix $\lambda$ tte 3572 , $\because \therefore$

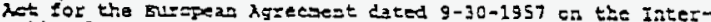
natlosil Thansort of Dacgeroun Goods on Rodes (ADR), datod

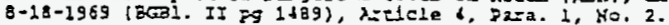

(Geranl Regulatiose for cla Dosentic and Intercational

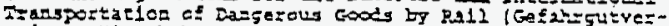
ordnus gisentan-Govil dated 7-22-19a5, id the vezsion as

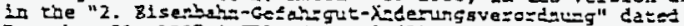
Decerber 21, 1987 (5CB). I FG. 2852) (Voluse II to the

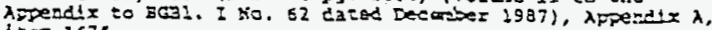
lEes 1678 . 


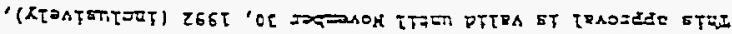
(n) $5 / \varsigma 50 \tau / 0$

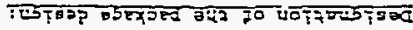

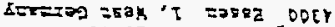

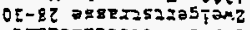

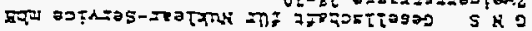

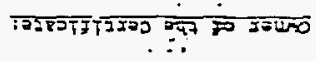

-

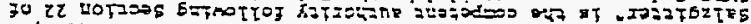

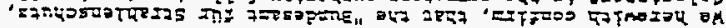

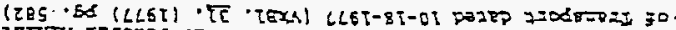

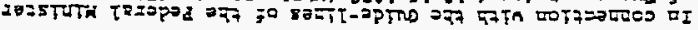

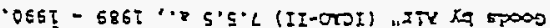

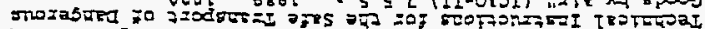

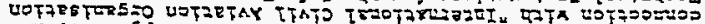

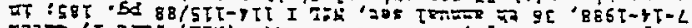

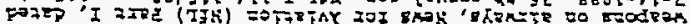

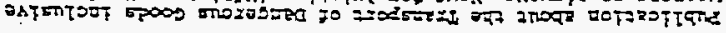

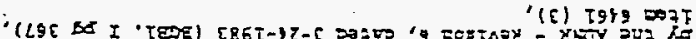

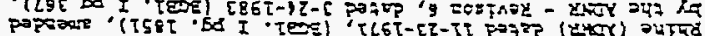

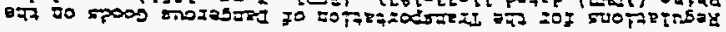

.T.

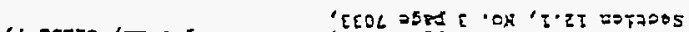

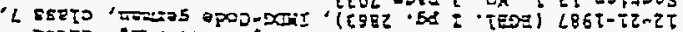

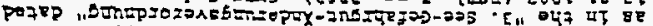

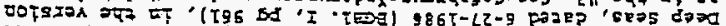

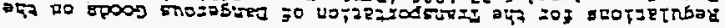

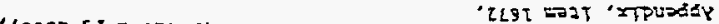

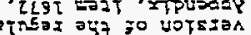

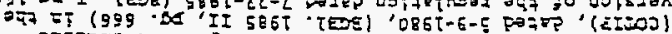

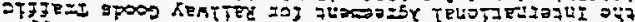

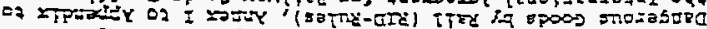

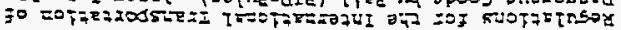


WHC-SD-TP-PDC-033 Rev. 1

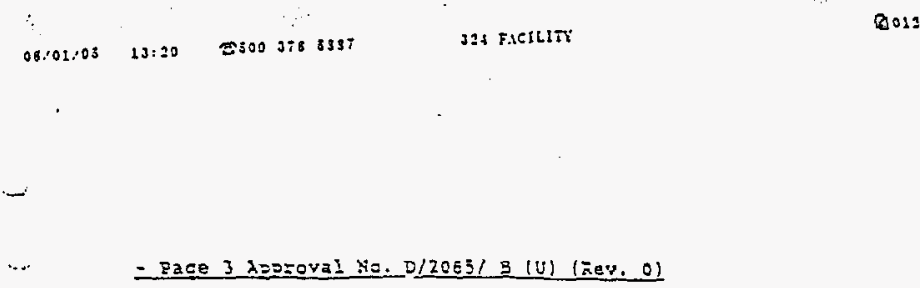

\section{Allewable contents:}

raxiru three stainless sterl caristers filled vith vilexifled

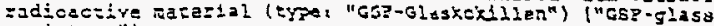
canisters")

They contents the following radbactive nuclides:

- Caesiuz-137, activicy: ax.: $1.1 \times 10^{16} \mathrm{~Bq} z=7$.

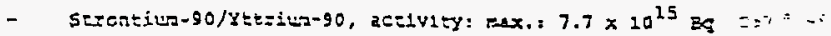

- a2tura: Tho:iur-oxid < 2 weight-l

- Rlutosiur <

- ratural vzanius $\leq 10 \mathrm{~g}$

Welght (ct the glast)

- aspex. $200 \times g$ 4titós

Trezel powas pez canlsier : max.: 2285 ratts

Dose $52 \pm 0$

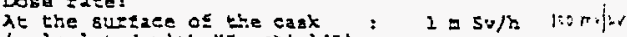

(calculated vith "Isoshield")

\section{Des $10 n$ of the Packagiss:}

The dealgn "Iranspot eask ois 12" wess the rogitrerents for a

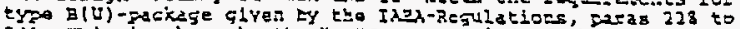

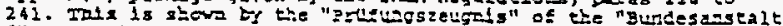
Ell yaterialfozchung und -prifu=g (BNy), dated 7-11-1983 I11e: $1: 5122111$.

Descziption of the packagis:

The shipping cask "Qis $12^{\prime \prime}$ conststs of a welded sealniesz stecl constrution with shieldirg of lead to ceatain three seainless

- steel canisters. Tha bodg of the casi 19 panfacturad as a

-; contalaer with a lead fliling betren thes. Bor eluselon of the

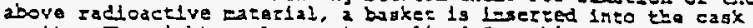

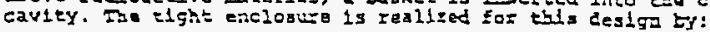




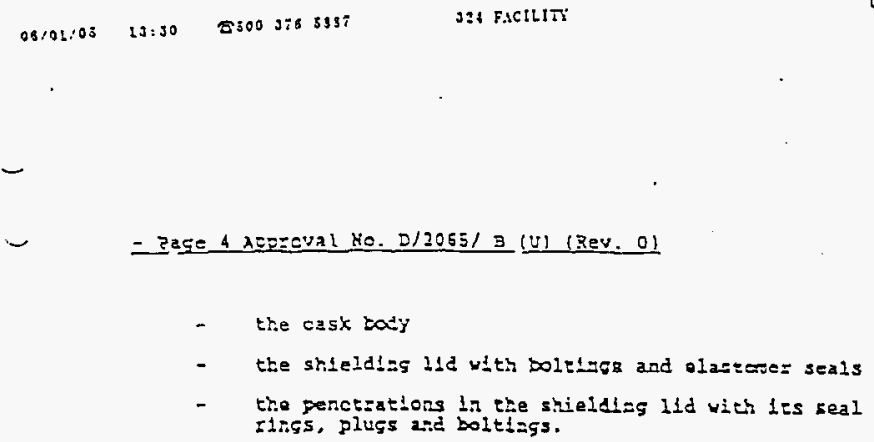

\section{Genezal Dzaving:}

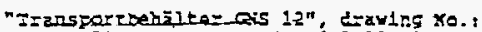

B 510.12 RвY. C, dated 3-22-1983

\section{condiclong 2nd dusectlos:}

1. All cuality asurazee procedures for doslga, controls durieg fabilcation and eperaelon gist be execued in ecopilasee

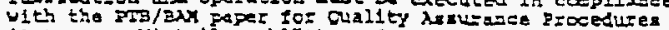

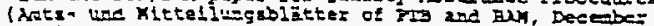

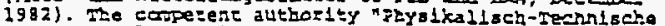
Buctenanstalt (zog)" rased tieze is to be zeplaced iy

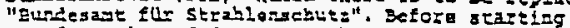

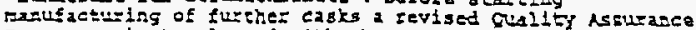
proxtare is to lieased with the copetent authorities. $\therefore$

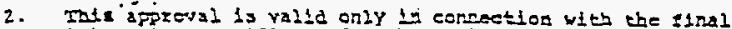
inipetion certficaso ses the serial casx conedzed.

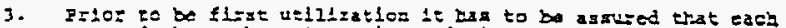
user of the package is regtstezed wibb burdegate filr sexahlerschuta and that the user confixus that be fas

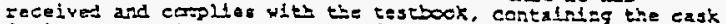
desisa afrzoval, the Procedure fez Esediting and raleterance and the Teatlis' procedure far Feriadie Inspections.

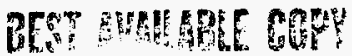


WHC-SD-TP-PDC-033 Rev. 1

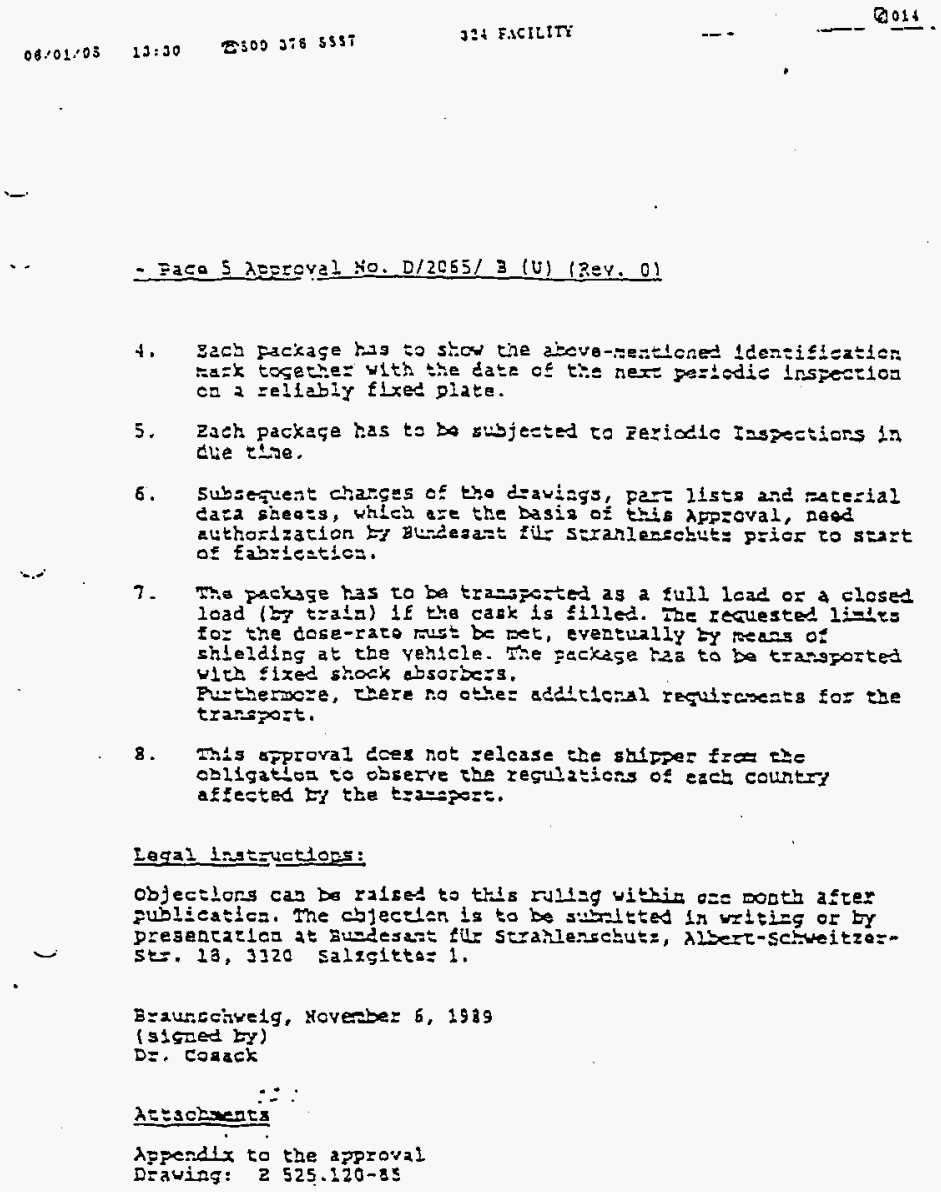

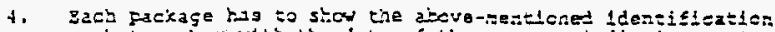
wath together with the date of tis ner gestedit inspeation ca a reltabiy flued giate.

5. Zach packege has to bo wojected to Feriodic Iaspectiors in clie riue.

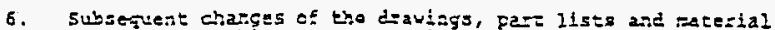
cata sineas, whleh aze the besiz of this AFpzoval, Deod

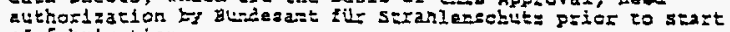
of Eabitetios.

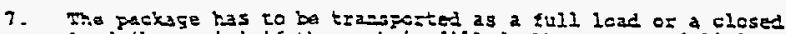

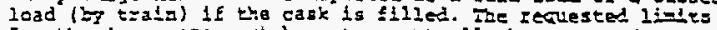
toz the dose-rato mist be ret, everewally ty reasg of sileidisg at the vehicle. The packese r.23 to be trapropted vith sized shodx absorbers.

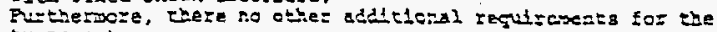
trassport.

8. This apporal cces not zelcase the shifpez fre tie coligation to observe the regul iticss of each country affected the tha-aport.

Lagal 120tzuctios:

objectlors cas bo ralses to this rulug withis ose Dooth after zublicatica. The cbjectan is to be subitted in writing or by

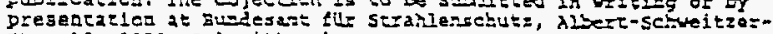
St. 13,3320 salegites 1 .

Bzxuscciste1g, Hovesber 6, 1989

(signed by)

$D=$. Coact

\section{$\lambda=$ Achenes}

dependtx to the approval

DIavizg: 2 525.120-85 
WHC-SD-TP-PDC-033 Rev. 1

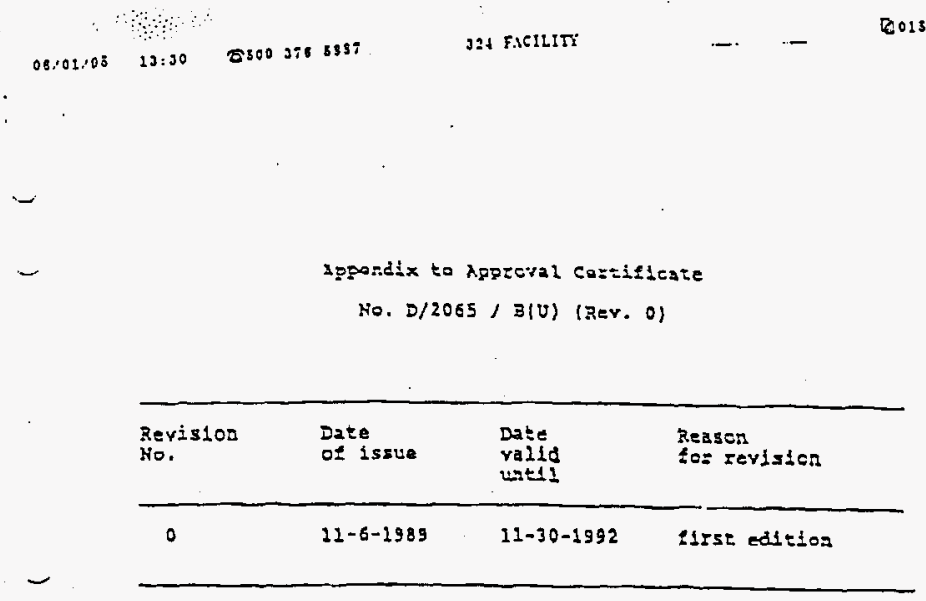




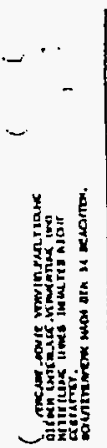

8

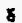

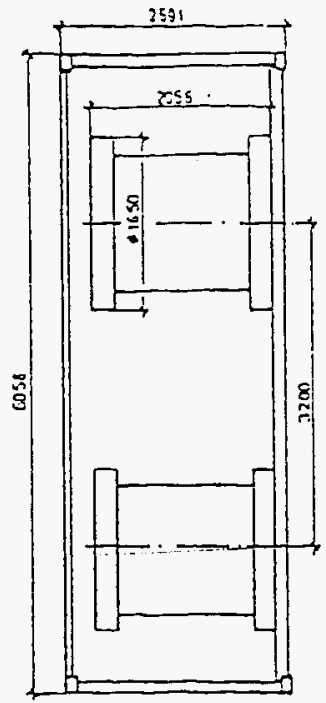

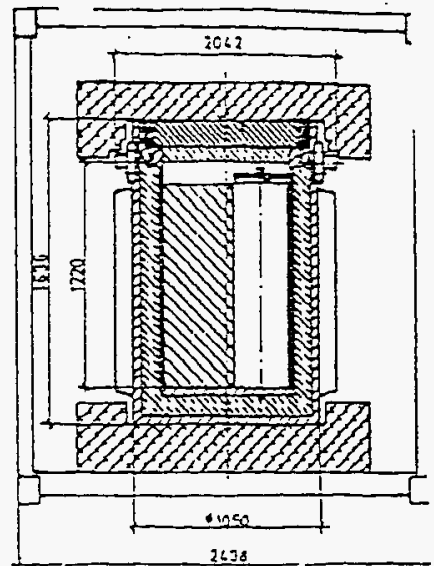

Xepozität/ 8ehälter cepocity of the packoging

3GSF - Kokillen / Conisters Wermeinhalt/Heot Conient max.6855 W

Mossen/Versondstück Mosses/Pockoge

Yersandstijex/ Pockage

$12.5 \%$

Kokillen/Conisters

$0,2 \% 1$

Leergevicht / Tore Heigh!

12.31

Deckelsiondömpter / Lid Shock ADsorber

0.81

Bodénstondämpfer l Eottom Shock Absorber

0.74

Primërdeckel / Primary Lid

Bei Yerwendung eines $20^{\circ}$ - Contoiners

With use of a $20^{\circ}$-Container

Transportgswicht/ Transport Weight

(max. 2 Yersondstudxa/Packoges)

Taro / Tore Weight

Mindestlütungsquerschnit: $/$ Hinimum Ventilation Ared $0,18 \mathrm{~m}^{2}$ 
WHC-SD-TP-PDC-033 Rev. 1

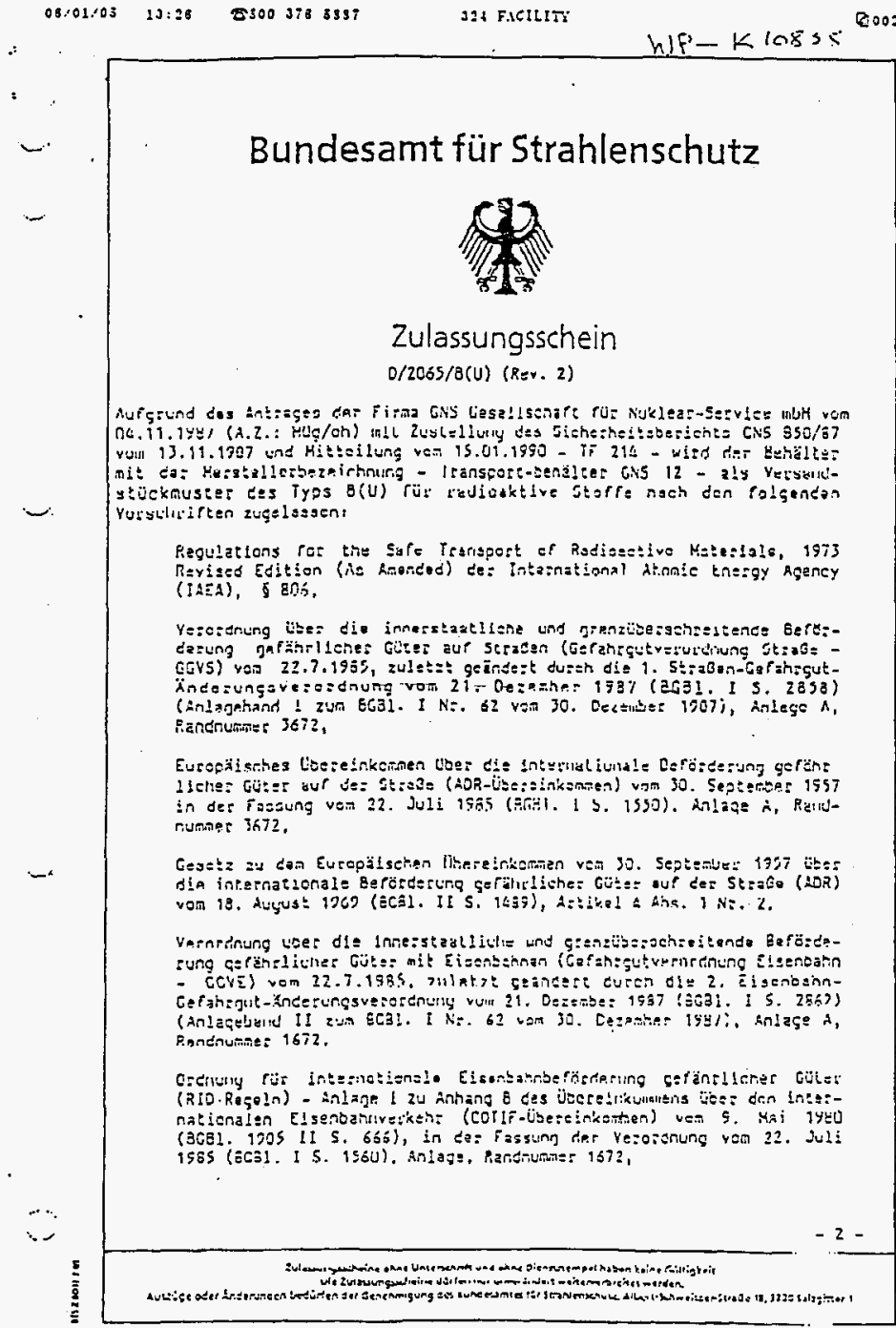

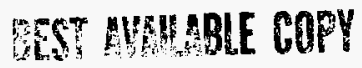


WHC-SD-TP-PDC-033 Rev. 1

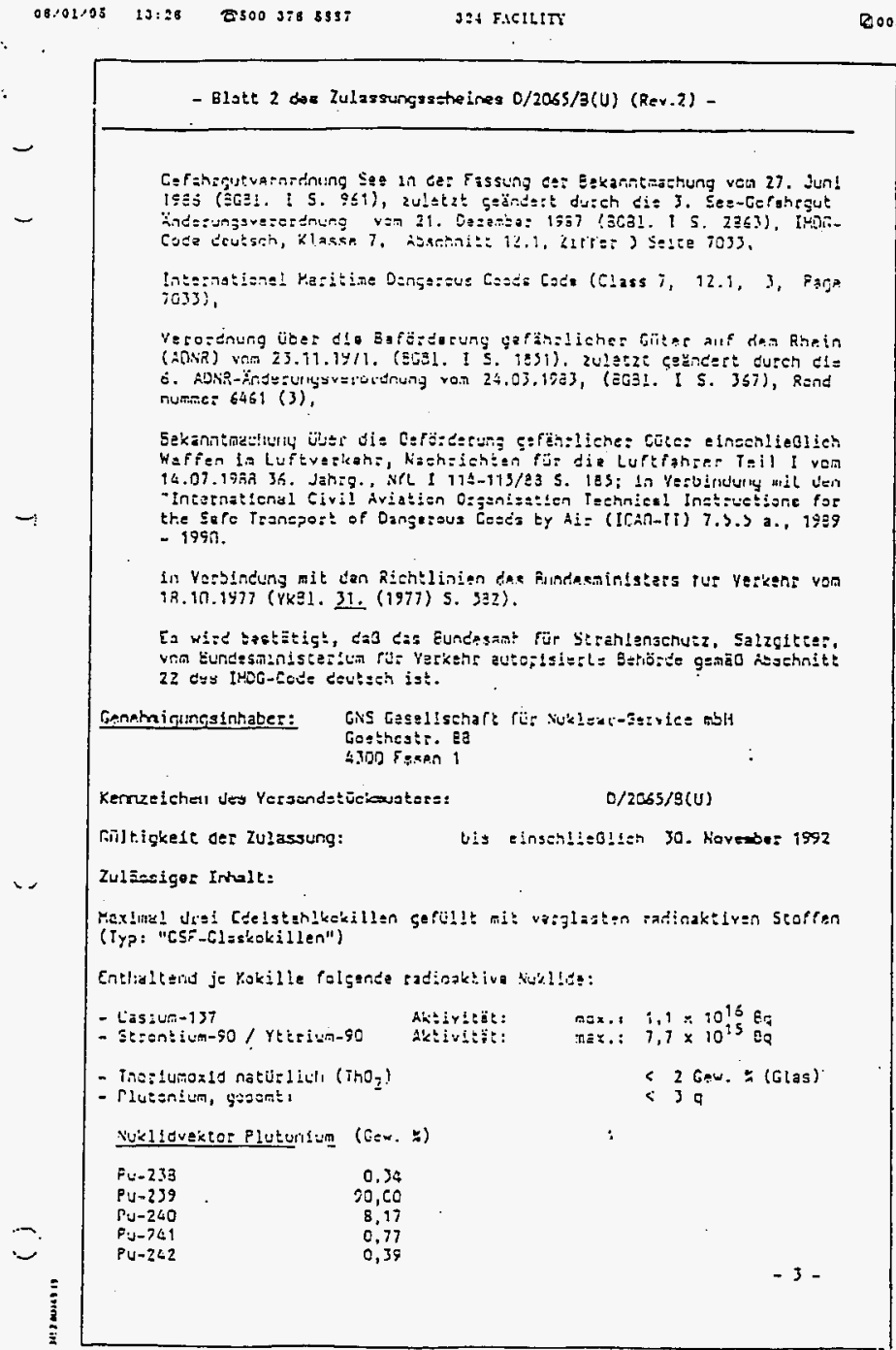


WHC-SD-TP-PDC-033 Rev. 1

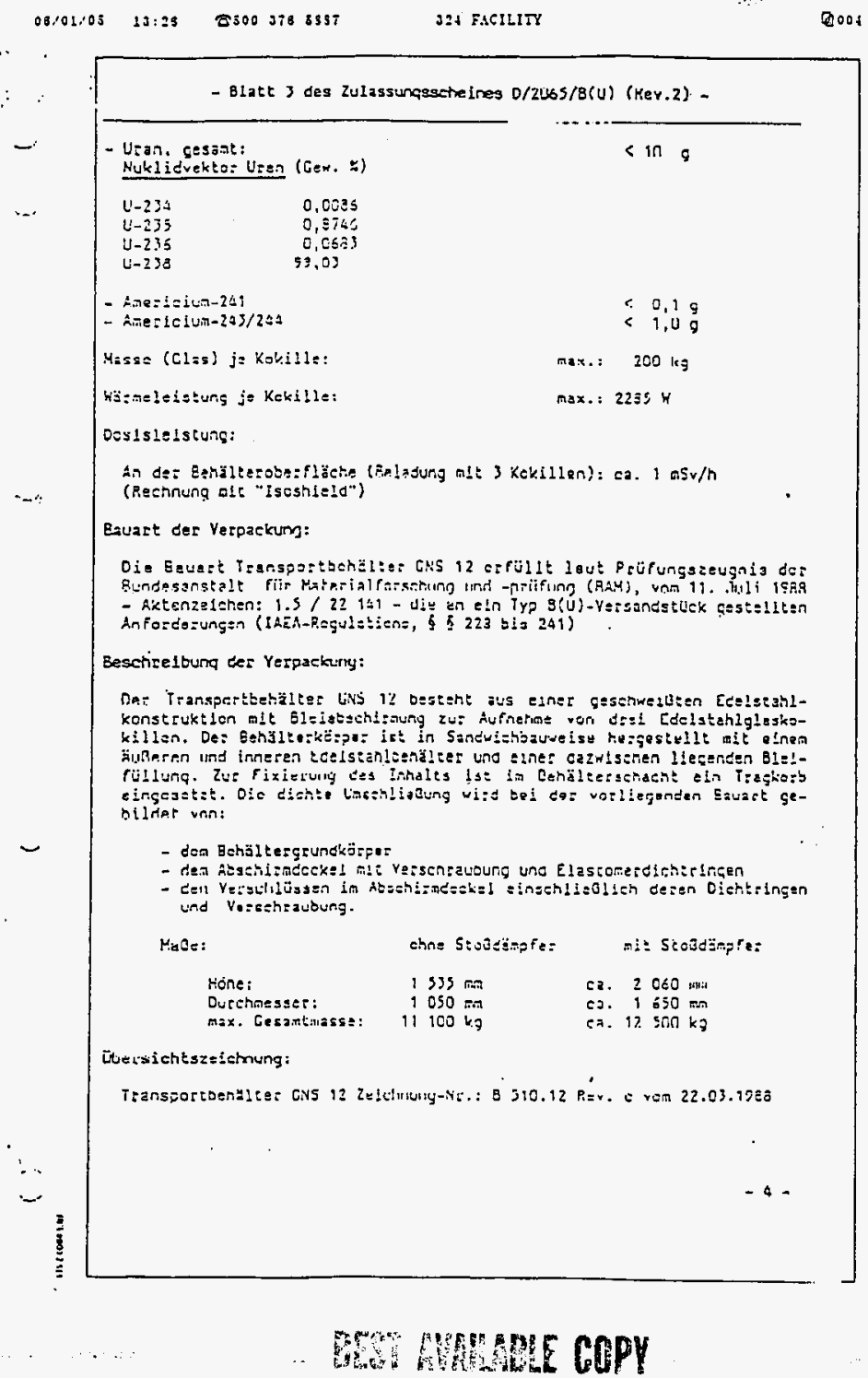


WHC-SD-TP-PDC-033 Rev. I

$08.01 .03 \quad 17: 27$

$8500376 \$ 557$

934 FACILIT:

8005

- Hlat.t. 4 des 7ulasoungssethofnea $0 / 2005 / B(U)$ (Rey.2) -

Nebendestim ungen und Hinveise:

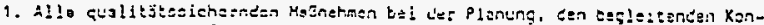

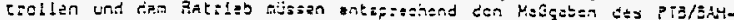

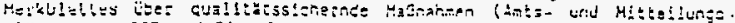

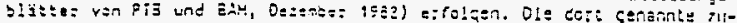

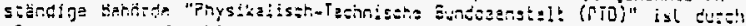

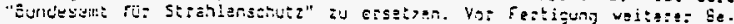

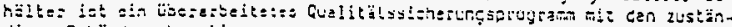
digen ingärden shotset immen.

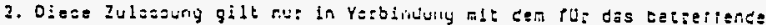

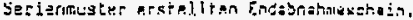

3. Es let elene:zuetellen, dra gish jede: Vtimendel tet Vespackung yoz des

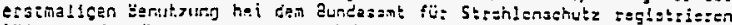

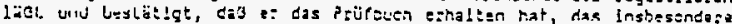

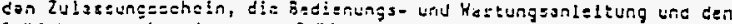

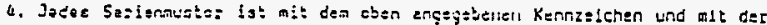

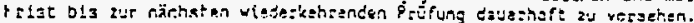

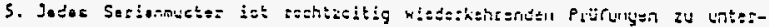
$2: \pm 1=n$.

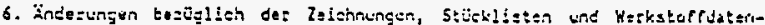

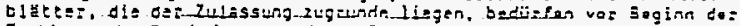
restlgung de: Genekimigung turth tes Eunseszat rut strahienschutz.

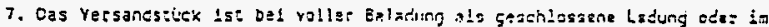

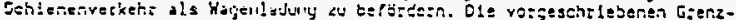

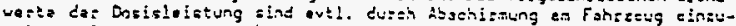

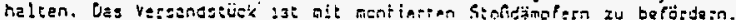

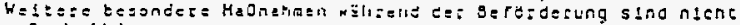
storderlieh.

8. Diese Zulessung entbindat den hbsendel lichl run der Motxendlqkelt,

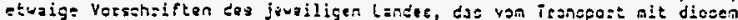
versandseüch begührt wled, zu beacnien.

Rechtsbehelfsbelehrung:

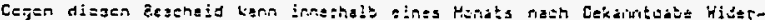

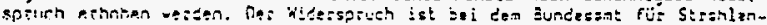

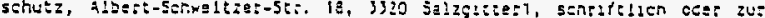
Nicdersaheift einzuleçen.

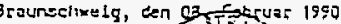

In Aurtiag

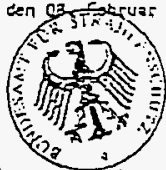

Anlues

व

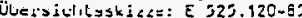

:

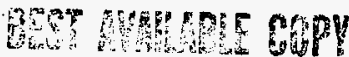


WHC-SD-TP-PDC-033 Rev. I

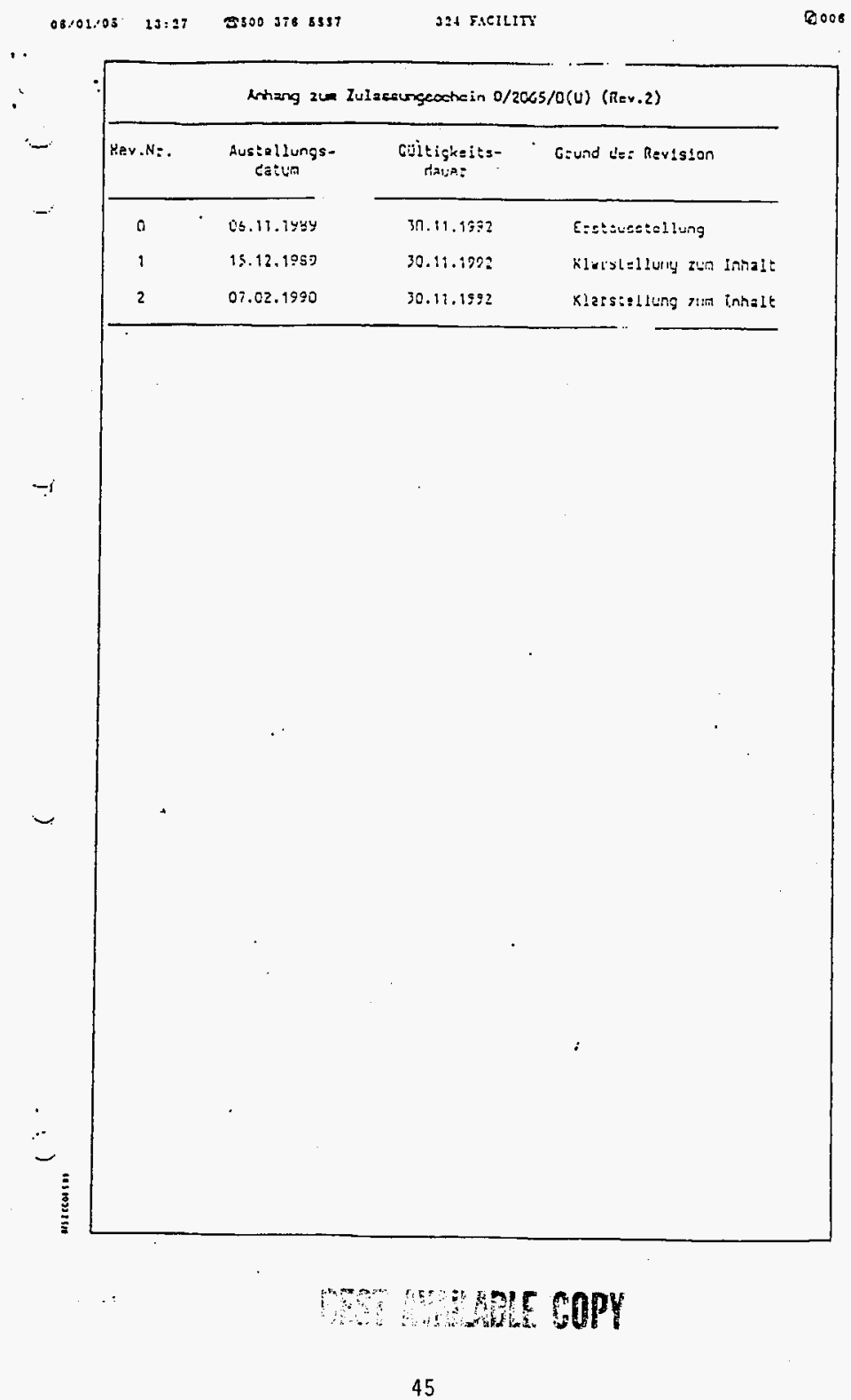


WHC-SD-TP-PDC-033 Rev. 1

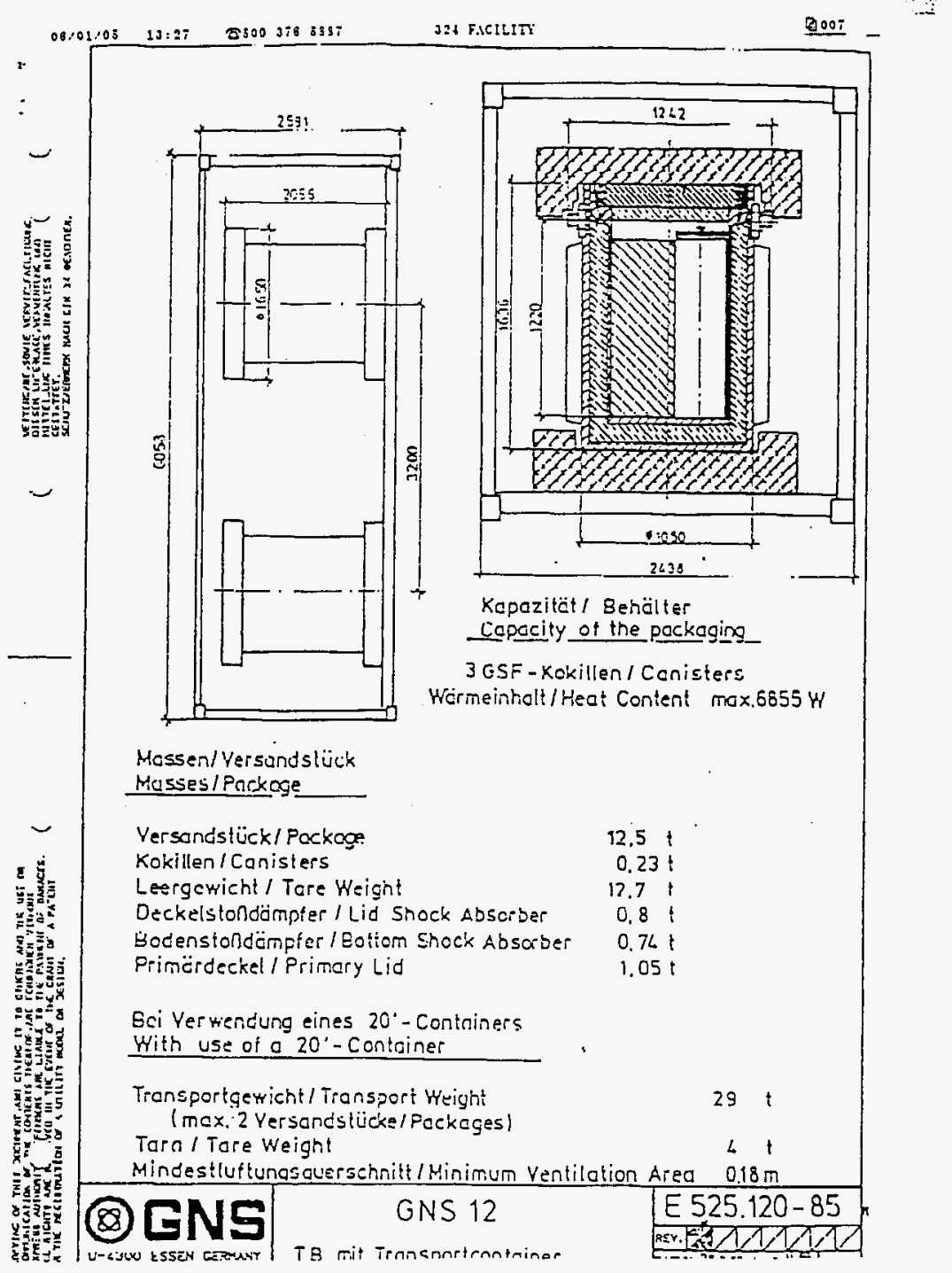

- IRP MEIIABIE COPY 
DISTRIBUTION SHEET

\begin{tabular}{|c|c|c|c|c|c|}
\hline \multirow{2}{*}{$\begin{array}{l}\text { To } \\
\text { Distribution }\end{array}$} & \multirow{2}{*}{\multicolumn{3}{|c|}{$\begin{array}{l}\text { From } \\
\text { Packaging Engineering }\end{array}$}} & \multicolumn{2}{|c|}{ Page 1 of 1} \\
\hline & & & & \multicolumn{2}{|c|}{ Date $03 / 27 / 96$} \\
\hline \multirow{2}{*}{\multicolumn{4}{|c|}{$\begin{array}{l}\text { Project Title/Work Order } \\
\text { GNS-12 Packaging Design Criteria (WHC-SD-TP-PDC-033) }\end{array}$}} & \multirow{2}{*}{\multicolumn{2}{|c|}{$\begin{array}{ll}\text { EDT No. } & \text { NA } \\
\text { ECN No. } & 630861\end{array}$}} \\
\hline & & & & & \\
\hline Name & MSIN & $\begin{array}{l}\text { Text } \\
\text { With All } \\
\text { Attach. }\end{array}$ & Text Only & $\begin{array}{l}\text { Attach./ } \\
\text { Appendix } \\
\text { Only }\end{array}$ & $\begin{array}{l}\text { EDT/ECN } \\
\text { Only }\end{array}$ \\
\hline $\begin{array}{l}\text { E. P. Clements } \\
\text { J. G. Field } \\
\text { J. R. Green } \\
\text { C. R. Hoover } \\
\text { E. F. Koehling } \\
\text { D. W. McNally } \\
\text { W. J. Schlauder } \\
\text { S. S. Shiraga } \\
\text { R. J. Smith } \\
\text { G. L. Swearingen } \\
\text { E. F. Votaw } \\
\text { K. S. Webster } \\
\text { Central Files } \\
\text { WHC-SD-TP-PDC-033 File }\end{array}$ & $\begin{array}{l}\text { Gl-13 } \\
G 1-11 \\
G 1-11 \\
G 1-11 \\
G 3-06 \\
G 1-11 \\
57-84 \\
G 1-11 \\
G 1-11 \\
K 8-37 \\
G 1-13 \\
P 7-75 \\
A 3-88 \\
G 1-11\end{array}$ & $\begin{array}{l}x \\
X \\
x \\
x \\
x \\
x \\
\\
x \\
x \\
X \\
x \\
X \\
x \\
X \\
\end{array}$ & & & $x$ \\
\hline
\end{tabular}

